\author{
Dr. sc. Nina Mišić Radanović, docentica \\ Sveučilišni odjel za forenzične znanosti Sveučilišta u Splitu ${ }^{1}$
}

\title{
PRISTANAK PACIJENTA NA MEDICINSKI ZAHVAT KAO RAZLOG ZA ISKLJUČENJE PROTUPRAVNOSTI
}

\author{
UDK: 614. 253. 8. \\ Primljeno: 10. IX. 2018. \\ Izvorni znanstveni rad
}

\begin{abstract}
Iako je pristanak oštećenika pojam koji je materijalno identičan u građanskom i kaznenom pravu, njegov je učinak različit. Dok u hrvatskom odštetnom pravu pravno valjan pristanak pacijenta kao oštećenika isključuje protupravnost medicinske intervencije, to nije slučaj u kaznenom pravu. Zbog složenosti ove problematike autorica obrađuju pojmove različitih vrsta pristanka pacijenta, od pretpostavljenog pristanka, zamjenskog ili surogat-pristanka do anticipirane naredbe/punomoći za slučaj nesposobnosti te posebno analizira sve uvjete potrebne za njegovu valjanost. Budući da u kaznenom pravu postoje različita stajališta o učinku pristanka oštećenika uopće, u radu su posebno prikazana dva suprotna stajališta zastupljena u komparativnom pravu u pogledu učinka pristanka pacijenta na medicinski zahvat. Autorica prikazuje normativni model ekskulpacijskog učinka pristanka prema kojemu nanošenje teške ili osobito teške tjelesne ozljede u liječenju ili djelatnosti u svrhu liječenja nije protupravno ako je pacijent dao pristanak u obliku i pod uvjetima predviđenima zakonom, te model prema kojemu je pristanak oštećenika bitan samo za biće djela.
\end{abstract}

Ključne riječi: informirani pristanak pacijenta, isključenje protupravnosti, nesavjesno liječenje

\section{UVODNE NAPOMENE}

Među pravnim institutima koji mogu isključiti odgovornost liječnika i drugih zdravstvenih radnika za kazneni i građanski delikt posebno mjesto pripada pristanku pacijenta na medicinsku intervenciju.

Premda je pristanak oštećenika pojam koji je materijalno identičan u građanskom i kaznenom pravu, njegov je učinak različit. U građanskom pravu pristanak oštećenika ima sljedeći učinak: onaj tko pristane da se na njegovu štetu poduzme štetna radnja ne može zahtijevati naknadu njome prouzročene štete. ${ }^{2}$ U odštetnom pravu pristanak pacijenta, dakle, isključuje protupravnost medicinske intervencije, pod uvjetom da

1 Doc. dr. sc. Nina Mišić Radanović, Katedra za pravne znanosti, Department for law sciences, Sveučilišni odjel za forenzične znanosti Sveučilišta u Splitu, Ruđera Boškovića 33, 21000 Split, University of Split, University Department of Forensic Sciences, e-mail adresa: nina.misic.radanovic@unist.hr.

2 Tko na svoju štetu dopusti drugome poduzimanje neke radnje, nema pravo od njega zahtijevati naknadu štete prouzročene tom radnjom (čl. 1054. st. 1. Zakona o obveznim odnosima, NN 35/05, 41/08, 125/11, 78/15, 29/18 dalje: ZOO). 
Dr. sc. Nina Mišić Radanović: Pristanak pacijenta na medicinski zahvat kao razlog za isključenje... Zbornik radova Pravnog fakulteta u Splitu, god. 55, 4/2018., str. 865.- 892.

je pravno valjan i da su izvedeni oni zahvati za koje je, nakon obavijesti o njima, dan pristanak. ${ }^{3}$ Drugim riječima, pristanak oštećenika već se tradicionalno smatra ekskulpacijskim razlogom te u slučaju kada je oštećenik pristao na štetu, štetna radnja sa stajališta pravnog poretka prestaje biti nedopuštena. Praktično, odštetni zahtjev parnični sud neće usvojiti, jer oštećenik proturječi svom ranijem držanju iz kojeg je proizlazilo da neće zahtijevati naknadu ako šteta nastane. Dakle, pristanak oštećenika u građanskom pravu ima prirodu razloga isključenja protupravnosti, ali i jednog specifičnog pravnog posla (ugovora između pacijenta i liječnika koji oboje potpisuju s informiranim pristankom). ${ }^{4}$

Međutim, odgovor na pitanje je li tako i u hrvatskom kaznenom pravu nije jednostavan. Koje su granice učinka pristanka pacijenta u medicinskom kaznenom i građanskom pravu, tj. ima li pristanak pacijenta apsolutni ili ograničeni pravni učinak te ima li tzv. pretpostavljeni pristanak samostalno mjesto u sustavu deliktne odgovornosti liječnika/zdravstvenih radnika, s obzirom na sličnost s krajnjom nuždom kao razlogom isključenja odgovornosti? Zbog toga je ovaj rad posvećen problematici kaznenopravnog učinka pristanka pacijenta, s usporedbom njegova učinka u građanskom pravu.

Svi medicinski zahvati (pregledi, pretrage, operacije i sl.) uključuju određena zadiranja u tjelesni integritet i slobodu pacijenta te, u pravilu, povređuju vrijednosti koje pravni sustav inače zaštićuje, čime određena ponašanja zdravstvenih radnika mogu ostvarivati biće nekog kaznenog djela i/ili mogu predstavljati štetnu radnju. Međutim, u određenim se slučajevima ipak ne mora raditi o kaznenom djelu, jer radnja/propust odnosno ponašanje zdravstvenog radnika mora biti i protupravno. Općenito, kada je riječ o razlozima isključenja protupravnosti u kaznenom pravu, ti se razlozi mogu prema izvorima nastanka svrstati u tri grupe. U prvoj su grupi oni razlozi koji su propisani u općem dijelu kaznenog zakona kao opći instituti mogući kod bilo kojeg kaznenog djela, primjerice nužna obrana i krajnja nužda. U drugu grupu razloga ulaze tzv. posebni razlozi propisani kod pojedinih kaznenih djela u posebnom dijelu kaznenog zakona, primjerice kod kaznenog djela neovlaštenog

Prema čl. 1054. st. 2. ZOO-a, ništetan je pristanak kojim je oštećenik pristao da mu se učini šteta radnjom koja je zakonom zabranjena, primjerice pristanak na nedopušteni pobačaj. O građanskopravnim posljedicama neinformiranja pacijenata šire Nikšić, S., „Građanskopravna odgovornost za liječenje bez pristanka“, Građanskopravna odgovornost u medicini, HAZU, Zagreb, 2008.; Boila, R. L., Respect for Human Dignity. Ethical and Legal Reflections Regarding the Breach of the Obligation to Inform the Patient, Postmodern Openings, 2013., vol. 4, Iss. 1, March, str. 39-54. Dostupno na: http://postmodernopenings. com, Dias Pereira, G. A., Existing challenges in medical liability: causation, burden of proof and informed consent. The ever-growing challenge of medical liability: national and European responses, Conference, Strasbourg, 2-3 June 2008, Council of Europe, 2009., str. 141-146.

4 O ugovornoj i izvanugovornoj odštetnoj odgovornosti šire Crnić, I., „Odštetna odgovornost liječnika i zdravstvenih ustanova s prikazom sudske prakse“, Hrvatska pravna revija, veljača 2009., str. 2841; Markenstein, F. L., „Country Report The Netherlands“, u: Zivilrechtliche Regelungen zur Absicherung der Patientenautonomie am Ende des Lebens (Regulations of Civil Law to Safeguard the Autonomy of patients at the End of Their Life), Springer, 2000., str. 741-772; Mujović-Zornić, H., Physician's error: medical or legal concept? 29 Med. \& L., 2010., str. 159-169, dostupno na: http://heinonline.org; Radišić, J., „Pravna priroda odgovornosti medicinskih poslenika i njihovog odnosa s pacijentima“, Pravni život, br. 9/10., 1992., str. 1759-1771; Bollweg, H. G., „Defining the extent of (medical) liability“, The evergrowing challenge of medical liability: national and European responses, Conference, Strasbourg, 2008. 
otkrivanja profesionalne tajne. U trećoj grupi nalaze se svi ostali razlozi isključenja protupravnosti koji nisu propisani kaznenim zakonom nego se spominju ili u posebnim zakonima ili u teoriji, primjerice pristanak oštećenika, povrede pri sportskim natjecanjima, dopuštene radnje u ratu te vršenje roditeljskog prava. ${ }^{5}$

U pravnoj literaturi postoje općenita stajališta da medicinske radnje označava tzv. uvjetna protupravnost ${ }^{6}$ jer se te radnje mogu smatrati protupravnima samo kada su nepropisne tj. kada nisu u skladu s važećim pravilima medicinske znanosti, struke i prakse, ili kada su obavljene bez potrebne pažnje i uz uvjet da između njih i smrti ili pogoršanja zdravlja bolesnika postoji uzročna veza. Zbog prihvaćanja različitih stajališta o pravnom temelju isključenja protupravnosti medicinskih postupaka ${ }^{7} \mathrm{u}$ teoriji su poznata tri modela: isključenje protupravnosti na temelju dopuštenog rizika, isključenje protupravnosti na temelju prava profesije te isključenje protupravnosti zbog pristanka pacijenta-oštećenika.

Isključenje protupravnosti na temelju dopuštenog rizika predstavlja teoriju prema kojoj, čak i ako je počinitelj stvorio pravno relevantan rizik, objektivno uračunavanje bit će isključeno, ako je riječ o dopuštenom riziku. Rizik je uopće značajka sveukupnog postupanja liječnika i ostalih zdravstvenih radnika. Vršenje medicinskih zahvata temelji se na ideji njihove društvene korisnosti te je protupravnost isključena, jer je, slično prometu, riječ o socijalno dopuštenom riziku. Teorije društvene korisnosti medicine u suštini predstavljaju neku vrstu neovisnog, generalnog i anticipativnog razloga isključenja protupravnosti pa je, u tom kontekstu, medicinska djelatnost jedina ljudska aktivnost koja uživa takav poseban kaznenopravni status. ${ }^{8}$ Dakle, društvo je spremno prihvatiti onaj dio rizika u kojem korist nadilazi štetu, ne i obrnuto. ${ }^{9} \mathrm{U}$ njemačkoj kaznenopravnoj dogmatici pojam dopuštenog rizika korišten je u vrlo različitim kontekstima, kao poseban razlog isključenja protupravnosti, kao oblik pristanka itd., a njegovo premještanje u područje objektivnog uračunavanja tekovina novije je doktrine. ${ }^{10}$

5 Tako Horvatić, Ž., Derenčinović, D., Cvitanović L., Kazneno pravo, opći dio 2, „, Kazneno djelo i kaznenopravne sankcije“", Zagreb, 2017., str. 39; Novoselec, P., Bojanić, I., Opći dio kaznenog prava, Zagreb, 2013., str. 164; Kurtović Mišić, A., Krstulović Dragičević, A., Kazneno pravo (Temeljni pojmovi i instituti), Split, 2014., str. 115; Tomić, Z., Krivično pravo I - krivično djelo, Pravni fakultet, Sarajevo, 2007., str. 182.

6 Radišić, J., Odgovornost zbog štete izazvane lekarskom greškom u lečenju i obaveštavanju pacijenta, Beograd, 2007.

7 O stajalištu prema kojemu je jedan velik dio diskusija o kaznenopravnim aspektima liječničkih intervencija, pogotovo u dogmatski hipertrofiranoj njemačkoj pravnoj teoriji, šire Damaška, M., „Neki krivičnopravni aspekti liječničkih zahvata“", Hrestomatija hrvatskog medicinskog prava, Pravni fakultet, Zagreb, 2016., str. 72.

8 Tako Korošec, D., „Pravice zdravnikov v Sloveniji in Evropi (osebnostnopravni vidik), Physicians ' Rights In Slovenia and Europe (From The Standpoint Of The Law Of Personal Rights)“, Zdrav vestn, 2006., 75, 648 .

9 Šeparović, Z., „Presađivanje dijelova ljudskog tijela“, Hrestomatija hrvatskoga medicinskog prava, Zagreb, 2016, str. 623 .

10 Školski primjer dopuštenog rizika jest vožnja sukladna svim pravilima cestovnog prometa, pa se ne može zanijekati da i u tom slučaju vozač stvara određeni rizik, no takav rizik nije nedopušten. Šire Martinović, I., „Problem uzročnosti u kaznenom pravu“, Hrvatski ljetopis za kazneno pravo i praksu, 
Isključenje protupravnosti medicinskih intervencija na osnovi prava profesije utemeljeno je na stajalištu prema kojemu se uvijek kada je zahvat proveden lege artis kažnjivost gubi zbog tzv. prava liječenja. ${ }^{11}$ Dakle, kada država dopušta obavljanje nekog zvanja, tada dopušta i onome koji obavlja to zvanje i svako potrebno ponašanje. Tako je dopušteno obavljanje zvanja liječenja koje nije moguće bez zahvata koja uključuju, inače kažnjive, tjelesne ozljede. U njemačkoj judikaturi prva odluka koja je postupak liječnika kvalificirala kao kazneno djelo tjelesne povrede - što je izazvalo oštro negodovanje liječničkog staleža - bila je donesena u slučaju amputacije stopala sedmogodišnjem djetetu, provedene protivno izričitoj volji njegova oca. Premda je amputacija bila apsolutno indicirana te obavljena lege artis i, u krajnjoj liniji, uspješna, Reichsgericht je u odluci posebno istakao da ni cilj ni uspjeh zahvata, kao ni „staleško pravo“, nisu u stanju opravdati zahvat u tijelo. Stav da jedino volja bolesnika ovlašćuje liječnika da tjelesnu povredu učini nekažnjivo prihvatio je i Savezni sud..$^{12}$ Dodjela diplome liječniku omogućuje, ali ga i obvezuje, raditi sve što je u njegovoj moći da liječi bolest. ${ }^{13}$

Unutar ove teorije opravdanje medicinskog djelovanja izvodi se iz tzv. ćudoredne svrhe ${ }^{14}$ zahvata odnosno stava da takvi zahvati nikada ne ulaze u područje kriminalnog ponašanja, ako su provedeni sa svrhom unapređivanja zdravlja po pravilima medicine, uz pristanak pacijenta i od strane profesionalno kvalificirane osobe.$^{15}$ Naime, liječnici i ostali zdravstveni radnici imaju opravdani interes na socijalnoj vrijednosti svoje djelatnosti te svaki zahvat u organizam ne predstavlja delikt tjelesne ozljede nego samo onaj koji organizam oštećuje i protivan je njegovim interesima. S obzirom na to da medicinski zahvat ide baš u smjeru očuvanja zdravlja i da namjera zdravstvenog radnika nije usmjerena na povređivanje nego na liječenje, teleološkim tumačenjem, on zapravo ne ispunjava obilježja bića kaznenog djela tjelesne ozljede. ${ }^{16}$ Dakle, medicinska djelatnost ne znači ugrožavanje nego zaštitu života i zdravlja ljudi, jer poduzimanje medicinskog zahvata predstavlja za bolesnika veću šansu nego nepoduzimanje liječenja. ${ }^{17}$

Isključenje protupravnosti medicinskih intervencija na osnovi pristanka oštećenika utemeljeno je na starom rimskom načelu da se onome tko pristaje ne čini nepravda (volenti non fit iniuria). Drugim riječima, kaznenopravna verzija starog

vol. 19, 1/2012., str. 94. Pojam Sozialadäquanz koji označava tzv. socijalnu adekvatnost stvoren je u njemačkoj pravnoj dogmatici, šire Baumann, J., Strafrecht, Allgemeiner Teil, 6th ed. 1974., str. 185.

11 Šire o tzv. liječničkom službenom pravu (njem. das ärztliche Berufsrecht) kao razlogu gubitka kažnjivosti za tjelesne ozljede prouzročene tijekom liječenja Miller, E., ,Kriminalno-pravna odgovornost liječnika“, Hrestomatija hrvatskog medicinskog prava, Pravni fakultet, Zagreb, 2016., str. 42.

12 Cit. prema Radišić, J., Pristanak pacijenta na lečenje i odgovornost..., str. 44.

13 Hughes, G., „Two Views On Consent In The Criminal Law“, Mod. L. Rev., 26, 1963., str. 242.

14 Miler, E., op. cit., str. 43.

15 Tako i Hughes: „It is of course beyond dispute in any legal system that surgical operations which are on the whole required for the health of the patient and which are done with the consent of the patient by properly qualified medical men who act with due care, are legal“. Hughes, G., op. cit., str. 233.

16 Damaška, M., op. cit., str. 73.

17 Bačić, F., Krivično pravo, opći dio, Zagreb, 1980., str. 218. 
ulpijanovskog načela civilnog prava da ono što se čini s voljom ozljeđenoga nije nepravo, znači da nema kaznenog djela ako osoba sama dopušta povredu svojih pravnih dobara. U pravnim sustavima common lawa uobičajeno je razmatrati problematiku legalnosti liječničkih i drugih medicinskih intervencija upravo u vezi s pristankom pacijenta. ${ }^{18}$ Premda hrvatsko kazneno zakonodavstvo uopće ne spominje pristanak oštećenika kao razlog isključenja protupravnosti nečijeg činjenja ili nečinjenja, judikatura i kaznenopravna teorija prihvaćaju ga u određenim slučajevima i pod određenim uvjetima.

\section{PRISTANAK PACIJENTA, PRETPOSTAVLJENI PRISTANAK, SUROGAT PRISTANKA I ANTICIPIRANE NAREDBE/ PUNOMOĆI ZA SLUČAJ NESPOSOBNOSTI}

Pristanak pacijenta predstavlja izjavu pacijenta kojom opunomoćuje liječnika/ zdravstvenog radnika da provede određene mjere liječenja ili terapije. Svrha pristanka pacijenta jest omogućiti mu da razmotri, procijeni i uravnoteži prednosti i nedostatke predloženog medicinskog tretmana, kako bi racionalno odabrao podvrgnuti se ili odbiti predloženi medicinski tretman. ${ }^{19}$

Pristanak valja razgraničiti od pojma suglasnosti koji označava pristanak jedne strane kojim je isključeno samo biće kaznenog djela odnosno biće svih onih kaznenih djela koja pretpostavljaju djelovanje protiv ili bez volje oštećenika (npr. spolni odnošaj bez pristanka i silovanje). U tradicionalnoj njemačkoj doktrini pojmovi pristanka (njem. Einwilligung) i suglasnosti (njem. Einverständnis) ne razlikuju se po svom psihičkom sadržaju nego po pravnim učincima. ${ }^{20} \mathrm{O}$ pristanku oštećenika čiji je pravni učinak isključenje protupravnosti radi se u slučaju kada je počinitelj povrijedio pravno dobro i time ostvario sva obilježja bića kaznenog djela, ali je oštećenik odobrio takvu povredu (npr. netko je drugoga zatvorio s njegovim pristankom čime je ostvario biće kaznenog djela protupravnog oduzimanja slobode). ${ }^{21}$

Staro rimsko načelo volenti non fit iniuria $\mathrm{u}$ kaznenom pravu nije nikada vrijedilo u apsolutnom opsegu, a i danas ima ograničene domete te se pitanje pravnog učinka pristanka oštećenika postavlja samo kod pojedinih kaznenih djela. ${ }^{22}$ Međutim,

18 Hughes, G., op. cit., 233.

19 Kraljić, S., „Informirana privolitev in pravica pacienta do obveščenosti $v$ enotah intezivne medicine (s pregledom evropske sodne prakse)", Zbornik radova s međunarodnog kongresa 1. Hrvatski kongres medicinskog prava s međunarodnim sudjelovanjem, 3.-5. studenoga 2017., str. 216.

20 Novoselec, P., Bojanić, I., op. cit., str. 206. Šire o razlici pristanka i suglasnosti Geerds, F., Einwilligung und Einverständnis des Verletzten, 1953. O suglasnosti koja isključuje kažnjavanje u medicinskoj profesiji Jefford, M., Moore, R., Improvement of informed consent and the quality of consent documents, Lancet Oncol, 2008., 9, 5, str. 485-93.

21 Šire o pristanku Drobac, A. J., Goodenough, R. O., „Exposing The Myth Of Consent“" Indiana Health Law Review vol. 12, 2 , 2015., str. 471-531. Dostupno na: ttps://journals.iupui.edu/

22 Usp. Koh, L. K., „Doctrine Of Consent In Criminal Law“, Malaya L. Rev. 9,1967., str. 192. 
Dr. sc. Nina Mišić Radanović: Pristanak pacijenta na medicinski zahvat kao razlog za isključenje... Zbornik radova Pravnog fakulteta u Splitu, god. 55, 4/2018., str. 865.- 892.

kako se pristanak oštećenika ne smatra razlogom isključenja protupravnosti per $s e$, pravna teorija ipak postavlja neke temeljne uvjete i granice, pa je moguće da pristanak oštećenika bude pravno relevantan kao razlog isključenja protupravnosti samo ako su kumulativno ispunjena dva uvjeta potrebna za tzv. opravdavajući ili ekskulpacijski pristanak.

Prvi uvjet za određeni učinak pristanka oštećenika jest disponibilnost povrijeđenog dobra, pa pristanak oštećenika može isključiti protupravnost samo kada se radi o pravnom dobru kojim oštećenik kao njegov ovlaštenik može slobodno raspolagati. Da bi odricanje od zaštićenog interesa bilo pravno dopustivo, takva dobra nikada ne mogu biti opća nego isključivo ona koja su u okvirima individualnih imovinskih i neimovinskih interesa, primjerice tjelesni integritet, čast, osobna privatnost, pravo vlasništvo i imovina. Unatoč stajalištu da su sva pravna dobra pojedinca zapravo opća dobra, ${ }^{23}$ ovdje se radi isključivo o onom individualnom dobru oštećenika na čijem održanju ne postoji interes društva za njegovim očuvanjem. Općeprihvaćeno je stajalište da se, primjerice, premda je život individualno dobro čovjeka, pristanak oštećenika (čak i njegov izričit i ozbiljan zahtjev) da ga se usmrti ne smatra razlogom isključenja protupravnosti, jer je život dobro za čijim održanjem postoji interes društva. Drugim riječima, postoje dobra čiji se opstanak i zaštita ne tiču samo njihovih titulara, pa je tako život čovjeka nedisponibilno pravno dobro. ${ }^{24}$

Drugi uvjet za učinak pristanka oštećenika jest tzv. valjanost pristanka. Pristanak je valjan ako ga je dala osoba sposobna za to, slobodno i prije počinjenja radnje, očitovano prema vani te ako nije opozvan prije dovršetka radnje.

Dakle, u medicinskoj djelatnosti pacijent u pogledu svog života i tijela ne uživa neograničenu autonomiju, jer načelo autonomije volje trpi određena ograničenja, čak i kada je u pitanju dobro koje je najneposrednije vezano za ličnost titulara dok se uvjeti valjanosti pristanka na medicinsku intervenciju tiču sposobnosti ili kompetentnosti pacijenta, kvalitete očitovanja njegove volje te trenutka davanja i sadržaja pristanka pacijenta. ${ }^{25}$

Pristanak na medicinsku intervenciju može dati samo punoljetan, poslovno sposoban pacijent odnosno pacijent sposoban za rasuđivanje koji u trenutku davanja izjave mora biti pri svijesti. Sposobnost za pristanak znači da je osoba

23 Korošec, D., Medicinsko kazensko pravo, Ljubljana, 2004., str. 123.

24 To je očigledno iz čl. 16. Zakona o zaštiti prava pacijenata (NN 169/04, 37/08, dalje: ZZPP): „Pacijent ima pravo prihvatiti ili odbiti pojedini dijagnostički, odnosno terapijski postupak, osim u slučaju neodgodive medicinske intervencije čije bi nepoduzimanje ugrozilo život i zdravlje pacijenta ili izazvalo trajna oštećenja njegovoga zdravlja." Tako i čl. 17. Zakona o pravima, obavezama i odgovornostima pacijenata (Službene novine Federacije BiH, broj 40/10, dalje: ZOPOOP) koji priznaje pacijentu pravo na slobodno odlučivanje o svemu što se tiče njegova života i zdravlja, osim u slučajevima kada to direktno ugrožava život i zdravlje drugih, s time da to pravo ne podrazumijeva eutanaziju.

25 Osnovni uvjeti za pristanak obaviještenog pacijenta jesu kompetentnost (engl. competence/ capacity), obavještavanje (engl. disclosure), razumijevanje (engl. understanding), dobrovoljnost (engl. voluntariness) i pristanak (engl. consent). Meisel A, Roth, L. H., ,, What we do and do not know about informed consent", JAMA, 1981., 246, 2473-2477. Cit. prema Vučemilo, L., Babić-Bosanac, S., Altarac, S., Borovečki, A., „Pristanak obaviještenog pacijenta s posebnim osvrtom na Hrvatsku“. Liječnički vjesnik, 2014., 136, str. 104. Tako i Jeremić, V., „Informirani pristanak: komunikacija između liječnika i bolesnika“, Jahr, vol. 4, no. 7, 2013., str. 528. 
svjesna njegova značenja i sposobna donijeti odluku. Ovlaštenik na pristanak mora, prema psihofizičkim pretpostavkama i zrelosti svoga razvoja, biti u stanju imati uvid u značenje dotičnog pravnog dobra i osnove raspolaganja odnosno, drugim riječima, ovlaštenik mora biti u mogućnosti jasno prosuđivati o značenju i dosezima odricanja od pravnog dobra te taj postupak pravilno procijeniti. ${ }^{26}$ Međutim, liječnik/ zdravstveni radnik ne može a priori poći od pretpostavke da pred sobom ima tzv. „razumnog pacijenta“ (engl. reasonable person), a istovremeno nije propisan postupak po kojem bi se utvrđivala ta sposobnost. ${ }^{27}$

Dakle, svaki, pa i samo prolazni nedostatak sposobnosti za pristanak protivan je pojmu valjanog pristanka. Pacijenti koji nisu pri svijesti, pacijenti s težom duševnom smetnjom te poslovno nesposobni i maloljetni pacijenti nisu sposobni izjaviti valjani pristanak, pa u tim slučajevima pristanak daje njihov skrbnik ili zakonski zastupnik. Slijepa osoba, gluha osoba koja ne zna čitati, nijema osoba koja ne zna pisati i gluhoslijepa osoba prihvaća pojedini dijagnostički odnosno terapijski postupak izjavom u obliku javnobilježničkog akta ili pred dva svjedoka iskazanom izjavom o imenovanju poslovno sposobne osobe koja će u njeno ime prihvaćati ili odbijati pojedini takav postupak. ${ }^{28}$ Pacijent daje pristanak na predloženu određenu medicinsku mjeru izričito, usmenim ili pisanim putem, ${ }^{29}$ ali za invazivne dijagnostičke zahvate i operativne zahvate obvezan je pisani pristanak.

Valjano očitovanje volje pretpostavlja da se pristanak na zahvat izjavljuje slobodno odnosno bez prisile, ozbiljno i izričito odnosno razumljivo. Pristanak je slobodan ako je dan bez bitnih nedostataka volje davatelja, slobodan od prisile (sile ili prijetnje) i zablude tj. nije valjan ako je iznuđen prijevarom, manipulacijom, nagovorom ili primjenom sile ili prijetnje. Stoga zatvorenici ne mogu dati takav slobodan pristanak, samo je iznimno moguće, primjerice kod uzimanja dijelova ljudskog tijela za bliskog člana obitelji. Drugim riječima, pristanak je redovito neopravdavajući ako počiva na prisili, prijevari, zabludi ili povredi obveze liječnika/ zdravstvenog radnika da pacijenta upozna s činjenicama. Kako pacijent sudjeluje u suodlučivanju o tijeku svoga liječenja, postavlja se pitanje u kojem pogledu treba sagledati utjecaj liječnika na donošenje odluke o tijeku liječenja i provođenju dijagnostičkih i terapijskih postupaka. Pri tome, svakako treba uzeti u obzir da je pacijent laik te da ne razumije liječenje i posljedice liječenja na način na koji ih

26 Ne uzima se u obzir samo određena dob već i sposobnost razumijevanja i rasuđivanja. O pitanjima svijesti i volje kod pristanka pacijenta Korošec, D.: Medicinsko kazensko pravo, str. 106.

27 Ako je osoba pravno kompetentna (poslovno sposobna), a presumira se da je svaka odrasla osoba pravno kompetentna za odlučivanje dok se ne dokaže drugačije, liječnik će prije zahvata procjenjivati njene mentalne sposobnosti za odlučivanje. Usp. Elliott, C., „Patients doubtfully capable or incapable of consent", Kuhse, H., Singer, P. (ed.), A Companion to Bioethics, 2001., str. 452-462.

28 Čl. 16. st. 4. ZZPP-a. Postavlja se pitanje što činiti u slučaju privremene nesposobnosti pacijenta kada je njegova sposobnost za razumijevanje i odlučivanje upitna. Smatra se da je nužno u takvoj situaciji postupiti kao u slučaju nesposobnosti pacijenta da izjavi pristanak odnosno poduzeti samo one radnje koje bi spriječile ugrozu života i zdravlja pacijenta ili trajno oštećenje zdravlja.

29 Pisani oblik davanja pristanka jest pravilo i izjavljuje se na unaprijed propisanom obrascu. Pristanak se može dati i prešutno odnosno konkludentnim radnjama iz kojih nedvojbeno proizlazi pristanak, $u$ skladu s pravnom maximom qui tacet consentire videtur u slučajevima kada pacijent pristupi liječenju odnosno liječenju se ne protivi, a nije izjavio pristanak. 
Dr. sc. Nina Mišić Radanović: Pristanak pacijenta na medicinski zahvat kao razlog za isključenje... Zbornik radova Pravnog fakulteta u Splitu, god. 55, 4/2018., str. 865.- 892.

razumije liječnik. Stoga se pacijentova odluka mora temeljiti i na povjerenju u liječnika odnosno na medicinskim savjetima i pomoći pri donošenju odluke. ${ }^{30}$

Uvjeti koji se tiču trenutka davanja pristanka pacijenta te sadržaja pristanka podrazumijevaju da se pristanak u pravilu daje unaprijed. ${ }^{31}$ Unatoč mišljenjima da pacijent, u pravilu, daje opći pristanak na liječenje odnosno na poduzimanje svih dijagnostičkih i terapijskih mjera radi ozdravljenja, pristanak se daje za točno određeni zahvat. Stoga, nije valjan generalni pristanak, jer pacijent zapravo nije informiran o pojedinim intervencijama. Tako primjerice, pacijent sa slomljenom nogom koji se prepustio liječenju nije pristao i na amputaciju noge, za koju je potrebna posebna suglasnost. Također, ako je pacijent potpisao pristanak za anesteziju, nije time potpisao i pristanak za kirurško liječenje. ${ }^{32}$ Iznimno, pristanak može biti dan i za više medicinskih usluga, ako one predstavljaju funkcionalnu cjelinu u okviru postupka liječenja. ${ }^{33}$ Ako je u tijeku izvođenja zahvata, za koji je prethodno dan pristanak, potrebno izvršiti još neki zahvat ili je potrebno proširiti zahvat izvan opsega danog pristanka, nužno je dobiti pristanak za novi zahvat ili za njegovo proširenje. Novi pristanak nije potreban jedino ako nepoduzimanje novog odnosno proširenog zahvata dovodi u opasnost život i zdravlje pacijenta ili je izgledno trajno oštećenje zdravlja pacijenta. ${ }^{34}$ Tako, primjerice, u slučaju da je potrebna operacija drugog organa ili odstranjivanje organa treba razlikovati postupanje u krajnjoj nuždi od onog kada se zahtjev može odgoditi. Naime, potrebno se pridržavati prihvaćenog načelnog stava tj. ako se zahvat može odgoditi, zatražiti dodatni (novi) pristanak ili ako njegovo odgađanje predstavlja rizik za pacijenta, zahvat provesti. ${ }^{35}$

30 Čizmić, J., „Pravo pacijenata na obaviještenost, s posebnim osvrtom na zaštitu tajnosti podataka o zdravstvenom stanju pacijenta“, Zbornik Pravnog fakulteta Sveučilišta u Rijeci vol. 29, br. 1, 2008. Zbog toga se uvodi pojam partnerskog odnosa između pacijenta i zdravstvenog radnika koji podrazumijeva jednak omjer snaga, međusobno uvažavanje i najvažnije, povjerenje u odnosu liječnik-pacijent, te je temelj za uspješno liječenje, ali i za napredovanje struke, a posljedično i za poboljšanje kvalitete zdravstvene usluge.

31 Pristanak za kirurški zahvat potpisan je na dan operacije, a prema iskazu oštećenice, potpisan je na hodniku operacijskog bloka (Okružni sud u Ljubljani, P-2135/03). Cit. prema Zečević, D., Škavić, J., Kaznenopravna i građanskopravna odgovornost liječnika - teorija i praksa, Medicinska naklada, Zagreb, 2012., str. 232.

32 Drugo vještačenje u predmetu KIR-1239/06 Županijskog suda u Rijeci. Ibid., str. 89.

33 Tako u čl. 18. st. 3. ZOPOOP-a.

34 Tako se prema čl. 23. ZOPOOP-a smatra da je pribavljen pretpostavljeni pristanak na proširenje operativnog zahvata od pacijenta ili pretpostavljeni pristanak njegovog roditelja, zakonskog zastupnika ili staratelja ako se tijekom invanzivnog operativnog zahvata pojavi potreba za proširenjem operativnog zahvata koji se nije mogao pretpostaviti, u nedostatku pacijentova pristanka odnosno pristanka roditelja, zakonskog zastupnika ili staratelja na obavljanje tog proširenog operativnog zahvata, te da se prošireni operativni zahvat može obaviti ako to zahtijeva hitnost stanja pacijenta jer bi njegovo neobavljanje dovelo do trajnog oštećenja zdravlja odnosno značilo bi akutnu prijetnju životu pacijenta, ili bi njegovo neobavljanje pacijentu donijelo nove moguće zdravstvene probleme kojima bi se mogao izvrgnuti u slučaju nepoduzimanja neke za njega, u tom trenutku korisne medicinske procedure.

35 Čl. 16. i 18. ZZPP-a. Usp. Žunić LJ., Prava $i$ dužnosti pacijenta u ostvarivanju zdravstvene zaštite, Split, 2016., str. 55. i Bošković, Z., „Prava pacijenata na primjerenu obaviještenost i odlučivanje“", Informator, br. 5343, od 21. svibnja 2005., str. 37. Drugim riječima, u slučaju kada kirurg tijekom operacije u kojoj je pacijent u općoj anesteziji, neočekivano utvrdi da je nužan opsežniji kirurški zahvat od planiranog ili da treba obaviti i neki drugi, smatra se da kirurg, uzimajući da postoji pretpostavljeni ili hipotetički pristanak, može započeti zahvat, proširiti ili izvršiti novi, pod uvjetom da je on nužan i 
Dr. sc. Nina Mišić Radanović: Pristanak pacijenta na medicinski zahvat kao razlog za isključenje... Zbornik radova Pravnog fakulteta u Splitu, god. 55, 4/2018., str. 865.- 892.

Nadalje, pacijent u svako doba može opozvati dani pristanak, pa čak i ako je zahvat već započeo. ${ }^{36}$ Pristanak se ne može opozvati jedino ako bi se time doveo u opasnost život i zdravlje pacijenta ili izazvalo trajna oštećenja njegova zdravlja. ${ }^{37}$ Zdravstveni radnik mora djelovati sa znanjem pristanka tj. mora znati da je davatelj pristanka (pacijent) kao titular pravnog dobra sporazuman s medicinskim zahvatom i da se izjasnio o tome prije samoga zahvata. Ako između izjave o pristanku i medicinskog zahvata postoji dulji vremenski razmak, potrebno je manifestirati ili očitovati da je pristanak još uvijek važeći i da ne postoji opoziv. U slučaju sumnje, liječnik/zdravstveni radnik mora zatražiti odgovarajuće informacije od pacijenta, a ako to nije moguće, može djelovati ako ne postoje neke druge uporišne točke za vjerojatni opoziv. ${ }^{38}$

Što se tiče sadržaja pristanka ili opsega informacija, mora se raditi o tzv. informiranom pristanku pacijenta (engl. informed consent) ili pristanku informiranog pacijenta ${ }^{39}$ kao njegovu pravu da bude na razumljiv način obaviješten i da, na temelju toga, pisano prihvati ili odbije predloženu medicinsku intervenciju. Priroda informiranog pristanka definira ga kao odobrenje pacijenta, koji je upoznat i razumije rizike i posljedice što ih liječenje povlači za sobom. ${ }^{40}$ Pristanak obaviještenoga ili informiranog pacijenta nije samo jedan događaj ili samo potpis, nego se radi o cijelom procesu $^{41}$ koji omogućuje pacijentu da slobodno odlučuje na temelju objektivnih

vitalno indiciran. Radišić, J., „Pristanak pacijenta na lečenje i odgovornost zbog lečenja bez punovažnog pristanka“, Evropska revija za pravo osiguranja, 1, 2012., str. 40.

36 Suprotno čl. 18. st. 5. ZOPOOP-a, po kojemu pacijent pristanak na predloženu medicinsku mjeru može usmeno opozvati sve dok ne započne njeno izvođenje.

37 Tumačenjem proizlazi iz čl. 16. st. 1. ZZPP-a.

38 Tako Kurtović Mišić, A., „Osnove kaznenopravne odgovornosti zdravstvenih radnika“, Zbornik radova s međunarodnog simpozija „Medicinsko pravo u sustavu zdravstvene djelatnosti”, Plitvice, 2015. str. 193-212.

39 Pojedini teoretičari ovaj pristanak najčešće nazivaju ,informirani pristanak“, što je doslovni prijevod s engleskog jezika. To nije ispravno, jer informiran može biti samo pacijent, a ne i njegov pristanak. Stoga je bolje koristiti izraz ,pristanak obaviještenog/informiranog pacijenta“ ili „pristanak utemeljen na obavještenju“. O pojmu i karakteristikama pristanka obaviještenog pacijenta detaljnije Radišić, J., „Pristanak pacijenta na lečenje $i$ odgovornost zbog lečenja bez punovažnog pristanka“, Evropska revija za pravo osiguranja, 1, 2012., str. 39-48; Gazdek, D., Informirani pristanak: korijeni, svrha, primjena i ograničenja, Split, 2013., 128 str.; Ivančić-Kačer, B., ,Informed consent ili informirani pristanak pacijenta na liječenje u hrvatskom pravu (s naglaskom na zaštiti prava liječnika)", Pravo i porezi, 6, 2009., str. 10-22; Bevanda, M., Čolaković, M., „Pravo pacijenta na obaviještenost i pristanak $i$ pravne posljedice liječenja bez pristanka pacijenta“, Zbornik radova Aktualnosti građanskog i trgovačkog zakonodavstva i pravne prakse br. 7, Mostar, 2009., str. 200-202; Sorta Bilajac, I., „Informirani pristanak - konceptualni, empirijski i normativni problemi, Informed consent-conceptual, empirical and normative issues“, Medicina fluminensis 2011., Vol. 47, No. 1, p. 37-47; Sjeničić, Z. M., „Pristanak pacijenta na meru lečenja“", Zbornik Matice srpske za društvene nauke, br. 129, Novi Sad, 2009., str. 45; Sorta Bilajac, I., „Informirani pristanak u UNESCO-vim bioetičkim dokumentima“, Jahr 2010.; 1(1): 77-85, Turković, K., ,Informirani pristanak i pravo na odbijanje tretmana u Republici Hrvatskoj“, Hrestomatija hrvatskoga medicinskog prava, Zagreb, 2016., str. 551-566.

40 ,Informed consent may then be defined as authorization to proceed with treatment given to a physician by a patient who knows and understands the risks and consequences that the treatment entails. " Weyandt, J. C., ,, Valid consent to medical treatment: need the patient know?", Duq. U. L. Rev., 4, 1965.1966., str. 451.

41 Tako Appelbaum, S. P., „Assessment of Patients 'Competence to Consent to Treatment“", N Engl J Med 2007, 357: str. 1834-1840. Dostupno na: http://www.nejm.org/doi/full/10. 
Dr. sc. Nina Mišić Radanović: Pristanak pacijenta na medicinski zahvat kao razlog za isključenje... Zbornik radova Pravnog fakulteta u Splitu, god. 55, 4/2018., str. 865.- 892.

informacija primljenih od liječnika, a koje su mu ponuđene na njemu jasan i razumljiv način. Informacije uključuju važna saznanja o bolesti, dijagnostičkim i terapijskim postupcima, rizicima tih postupaka i svim drugim mogućnostima liječenja. Dakle, razumijevanje prirode i svrhe predloženog medicinskog postupka, razumijevanje rizika i nuspojava medicinskih postupaka, razumijevanje drugih metoda liječenja i posljedica neliječenja nužan su sadržaj svakog valjanog pristanka. Stoga, ordinirajući liječnik mora priopćiti odgovarajuće informacije pacijentu o prirodi, svrsi, tijeku zahvata, vjerojatnosti uspjeha i uobičajenim rizicima, ${ }^{42}$ tako da pacijent ima slobodan izbor prihvatiti ili odbiti određeni tretman. Informacija ili obavijest mora biti jasna, savjesna (čestita) i odgovarajuća, pri čemu su jasne one informacije koje pacijent može razumjeti, savjesne su one koje ništa namjerno ne kriju dok su odgovarajuće one koje su prilagođene posebnostima individualnih uvjeta i nisu općenite ${ }^{43}$ Drugim riječima, informacija bi trebala biti nedvosmislena i kratka, uz minimalnu uporabu stručnih izraza, pacijentu dostupna i pravodobna. ${ }^{44}$

Koncept informiranog pristanka, kojim se poštuje volja pojedinca da sam odlučuje o tome hoće li na njemu biti izvršena bilo kakva medicinska intervencija i u koje svrhe, danas je zastupljen u svakodnevnoj kliničkoj praksi te ima klinički, etički ${ }^{45}$ i pravni aspekt. ${ }^{46}$ Dužnost obavještavanja pacijenta drži se sastavnim dijelom liječenja, prilagođena svakom pacijentu dok opseg predstavlja pravno pitanje te je sudska praksa većine europskih država usvojila u pogledu te dužnosti

42 Slučajevi medicinskih kontraindikacija ili terapeutski privilegij može iznimo osloboditi liječnika od obveze da pacijenta obavijesti o rizicima medicinske mjere kada bi to nepovoljno utjecalo na pacijenta i nanijelo mu znatnu tjelesnu ili psihičku štetu. Tako Savezni sud Njemačke priznaje medicinsku kontraindikaciju samo ako bi obavještavanje o rizicima vodilo ozbiljnom i neotklonjivom oštećenju pacijentova zdravlja. Radišić, J., „Dužnost lekara da pacijenta obavesti o rizicima predložene medicinske mere i njegova odgovornost - poseban osvrt na praksu nemačkih i austrijskih sudova“, Evropska revija za pravo osiguranja, 2, 2012., str. 38. Usp. Zečević, D., Škavić, J., op. cit. str. 23.

43 Šire o ,the patient's right to a personalized information “ Mihut, A., „The Respect for Human Dignity Throughout Life as Reflected in the New Civil Code“, Societate şi Politică, 2011., 5(9), str. 76. Dostupno na: http://socpol.uvvg.ro/image.

44 U predmetu R. R. protiv Poljske, nakon pregleda ultrazvukom u osamnaestom tjednu trudnoće, podnositeljica zahtjeva obaviještena je kako postoji mogućnost fetalne malformacije. Odmah je izrazila želju da prekine trudnoću ako se dijagnoza potvrdi. Preporučeno joj je da se podvrgne genetskom ispitivanju amniocentezom, ali to je ispitivanje obavljeno tek u dvadeset trećem tjednu trudnoće, nakon što su prethodno više puta njezin liječnik i niz drugih liječnika odbili dati joj potrebna objašnjenja i upute. Kada je, dva tjedna poslije, dobila rezultate koji su potvrdili da plod ima Turnerov sindrom, za prekid trudnoće bilo je prekasno. U postupku pred nacionalnim sudovima podnositeljica nije uspjela sa zahtjevom za kaznenim progonom liječnika, ali joj je u građanskom postupku dosuđena naknada štete zbog propusta liječnika da joj pravodobno pruže informacije relevantne za donošenje odluke. Povreda je utvrđena i u odnosu na propust da se evidentira odbijanje davanja uputa. $R$. R. protiv Poljske, presuda od 26. svibnja 2011., zahtjev br. 27617/04. Vidi Bagić, S., „Informirani pristanak u sudskoj praksi“, Zbornik radova, 2. Hrvatski simpozij medicinskog prava, Vodice, 2016., str. 273.

45 Obrazac informiranog pristanka, čak i ako je vrlo detaljan, nije pravi odgovor na poteškoće u stjecanju empatije prema pacijentu. De Palma, A., „Conoscenza, errori, comunicazione con il paziente e consenso consapevole (Knowledge, mistakes, communication with patients and informed consent)“, Italian Journal of Medicine, 2013., 3(1), str. 67-71.

${ }^{46} \mathrm{O}$ tzv. ugovorenom pristanku (engl. negotiated consent) kao alternativi tradicionalnom informiranom pristanku, koji je u medicini posebno primjenjiv za starije osobe Smith, P. G. II, „The Vagaries Of Informed Consent", Indiana Health Law Review, vol. 1, 2004., str. 123. 
Dr. sc. Nina Mišić Radanović: Pristanak pacijenta na medicinski zahvat kao razlog za isključenje... Zbornik radova Pravnog fakulteta u Splitu, god. 55, 4/2018., str. 865.- 892.

tzv. „razumni liječnički standard”. ${ }^{47} \mathrm{U}$ svakom slučaju, opseg informacija određen je ciljem informiranja pacijenta, davanjem mogućnosti pacijentu da kao laik donese odluku o (ne)prihvaćanju predložene medicinske intervencije odnosno istraživanja. U pogledu opsega informiranja, postoji gotovo opće pravilo: što je medicinska intervencija manje indicirana to opseg informiranja mora biti veći. Tako su visoki zahtjevi postavljeni za kozmetičko-estetske zahvate kod kojih liječnik mora striktno objasniti šanse za uspjeh i povezane rizike odnosno obavijestiti pacijenta o razlozima za i protiv intervencije sa svim njenim posljedicama. ${ }^{48}$

Uvjeti za valjanost pristanka pacijenta na liječenje jednaki su i za slučaj tzv. zamjenskog pristanka. Zamjenski pristanak ili surogat-pristanak (engl. legally authorized representative ${ }^{49}$ postoji u slučajevima u kojima pristanak na liječenje daju zakonski zastupnik ili skrbnik kada je propisima na njih prebačeno ovlaštenje na davanje pristanka. Također, zamjenski pristanak daje i osoba od povjerenja kod obvezujuće izjave ili punomoći za slučaj nesposobnosti, koja zapravo predstavlja tzv. anticipiranu naredbu (engl. advance directive/living will) odnosno anticipiranu punomoć (engl. proxy directives). Radi se o unaprijed izraženoj volji u slučaju buduće nesposobnosti osobe tj. kada ta osoba više ne bude sposobna izraziti svoju volju. ${ }^{50}$ Osoba od povjerenja jest ona na koju je obvezujućom izjavom

47 U slučaju spora sud je ovlašten i dužan utvrditi je li u konkretnom slučaju liječnik dosegnuo standard koji se po zakonu traži. Šire Čizmić, J., op. cit. Šire o slučajevima i stajalištima američkih sudova Cantrell, C., „A Physician's Liability for Experimental Procedures“, Med Law, 1984., 3, 339-344. Slučaj koji je prvi kreirao neke standarde što ih informirani pristanak mora sadržavati jest spor Martina Salga protiv bolnice Stanford University. Martin Salgo je u tužbi naveo da je njegov liječnik bio nemaran u ispunjavanju procedure, jer ga nije informirao o komplikacijama i riziku za paralizu koji postoji nakon translumbalne aortografije kojoj je on bio podvrgnut i nakon koje je ostao paraliziran. Sud je presudio u korist Salga, obrazlažući svoju odluku kako je za pacijenta važno, a možda i krucijalno potpuno iznošenje činjenica potrebnih za informirani pristanak. U slučaju Natanson sud je definirao osnovne elemente sadržaja informiranja: prirodu bolesti, vjerojatnost uspjeha predloženih postupaka ili alternativnih postupaka, rizike nesretnih rezultata te nepredvidljivih stanja unutar tijela. Cit. prema Gazdek, D., op. cit., str. 8 .

U pogledu opsega informacija oblikovala su se tri modela: a) standard razumnog (tipičnog) zdravstvenog radnika; b) standard razumnog (prosječnog) pacijenta, c) subjektivni standard (individualnog pacijenta). Sire De Bord, J., Informed Consent, dostupno na: https://depts.washington.edu/bioethx/topics/ consent.html.

48 Tako Wienke, A., „Errors and pitfalls: Briefing and accusation of medical malpractice - the second victim", German Medical Science Current Topics in Otorhinolaryngology - Head and Neck Surgery 2013, vol. 12, str. 4. Dostupno na: http://www.egms.de/static/pdf/journals/cto/ Liječnik je dužan odgovoriti na sva pitanja koja postavi pacijent, čak i naknadno, te ne smije dopustiti da obavještenje o dijagnozi i prognozi bolesti daje netko drugi, npr. medicinska sestra, bolničar, stažist ili dr. O različitim informacijskim i komunikacijskim potrebama pacijenata koji sudjeluju u istraživanju šire Hallinan, P. Z., Forrest, A., Uhlenbrauck, G., Young, S., McKinney, R. JR., „Barriers to Change in the Informed Consent Process ", A Systematic Literature Review, May-June 2016, vol. 38, iss. 3. Dostupno na: http://www. thehastingscenter.org/irb article/.

49 Zakonski je zastupnik pojedinac, sudsko ili drugo tijelo ovlašteno u skladu s važećim zakonima pristati u ime potencijalnog subjekta na sudjelovanje subjekta u medicinskom postupku. Adams, D. C., „Consent to medical treatment of a minor under the Family Code“, Baylor L. Rev., 27, 1975., str. 328.

50 Šire o anticipiranoj punomoći Milas Klarić, I., „Izjava volje za slučaj nesposobnosti“, Hrvatska pravna revija, 5, 2010., str. 61-71. Dok su oporuke s učincima za života uvijek jednostrani pravni poslovi, anticipirane punomoći stvaraju obvezujuće učinke tek prihvatom naloga opunomoćenika na način da ga obvezuju i ovlašćuju donositi odluke sukladno danoj ovlasti. Usp. Burkle, M. C., Mueller, S. P., Swetz, M. K., Christopher Hook, C. C., Keegan, T. M., Physician perspectives and compliance with patient advance 
Dr. sc. Nina Mišić Radanović: Pristanak pacijenta na medicinski zahvat kao razlog za isključenje... Zbornik radova Pravnog fakulteta u Splitu, god. 55, 4/2018., str. 865.- 892.

prenesena ovlast davanja/odbijanja pristanka umjesto davatelja te izjave. Glavna je značajka obvezujuće izjave u tome da se primjenjuje samo onda kada osoba koja ju je dala nije sposobna dati pristanak za medicinske postupke određene tom izjavom, drugim riječima, tek onda kada se utvrdi da neka osoba nije sposobna dati pristanak za medicinske postupke. Ona obvezuje sve pružatelje medicinskih usluga koji primjenjuju medicinske postupke za koje se zahtijeva pristanak pacijenta te od liječnika zahtijeva ponašanje unutar izražene volje sve dok nema dokaza da ju je pacijent opozvao. ${ }^{51}$ Pri tome, naravno, sam davatelj izjave određuje opseg medicinskih postupaka za koja prenosi pravo odlučivanja na osobu od povjerenja, pa se može raditi ili samo o jednom ili o više postupaka. ${ }^{52}$ Kako je zamjenski pristanak zapravo djelovanje u interesu oštećenika, tako i uvjet koji se tiče sposobnosti uvida i rasuđivanja važi i za navedene osobe, jednako kao i svi drugi uvjeti nužni za valjani pristanak.

Dalje, postoje slučajevi u kojima liječnik djeluje bez prethodno jasno izraženog dobrovoljnog pristanka, ali u najboljem interesu pacijenta. U tim slučajevima, na temelju stvarno postojećih okolnosti može se razumno pretpostaviti da bi pacijent sigurno pristao na medicinsku intervenciju. Riječ je o stanjima koja privremeno uzrokuju ograničenje pacijentove autonomije, primjerice hitna stanja u kojemu je vitalno ugrožen život ili stanje kome u kojoj je čovjek nesposoban za odlučivanje, ili neko duševno stanje i bolest koje dovode osobu u nesposobnost za racionalno rasuđivanje na način da ona ugrožava svoj ili tuđi život. Dakle, pretpostavljeni i/ ili hipotetički pristanak pacijenta postoji ako pacijent nije dao svoj pristanak, jer zbog njegove nedostupnosti pristanak za medicinsko djelovanje nije bilo moguće pribaviti, primjerice pacijent bez svijesti nije u mogućnosti pristati na kirurški zahvat. ${ }^{53}$ Pretpostavljeni pristanak ima određene sličnosti s institutom krajnje nužde.

directives: the role external factors play on physician decision making, BMC Medical Ethics 2012, $13-$ 31. Dostupno na: http://www.biomedcentral.com/1472-6939/13/31 i Wnick, J. B., ,Advance Directive Instruments for Those with Mental Illness“, University of Miami Law Review, 51, 1996.-1997., str. 57-95.

51 Usp. Selinger, P. C., „The right to consent: Is it absolute?" , British Journal of Medical Practitioners, 2009., vol. 2, no. 2, str. 52. Dostupno na: http://www.bjmp.org/files/june2009/bjmp0609selin Usp.

Peppin, F. J., ,Physician Neutrality and Patient Autonomy in Advance Directive Decisions“, Law \& Medicine, Vol. 11, No. 1, 1995., str. 13-27.

52 Međutim, iz sadržaja obvezujuće izjave isključena je mogućnost da osoba od povjerenja dade pristanak za uključivanje osobe $\mathrm{s}$ duševnim smetnjama u biomedicinska istraživanja, kastraciju elektrokonvulzivno liječenje. Više o obvezujućoj izjavi Mišić Radanović, N., „Postupak prisilne (civilne) hospitalizacije prema Zakonu o zaštiti osoba s duševnim smetnjama“, Zbornik radova „Aktualnosti građanskog procesnog prava - nacionalna i usporedna pravnoteorijska i praktična dostignuća“, 2015. str. 410-413. Usp. Zečević, D., Škavić, J., op. cit., str. 26.

53 O hipotetičkom i pretpostavljenom pristanku pacijenta šire Korošec, D., Medicinsko kazensko pravo, 2. izdanje, Ljubljana, 2016., str. 218. Pretpostavljeni pristanak uvijek je supsidijaran u odnosu na institut pristanka povrijeđenog. Svaka izjavljena volja pasivnog subjekta primarna je u odnosu na hipotetičku volju pretpostavljenog pristanka. Tek ako ova volja nije poznata, može se prijeći na ispitivanje uvjeta pretpostavljenog pristanka. Śire o pojmu pretpostavljenog pristanka Vuković, I., „Pretpostavljeni pristanak u krivičnom pravu“", Crimen (V) 1, 2014., str. 50-52. 


\section{UČINAK PRISTANKA PACIJENTA NA MEDICINSKI ZAHVAT U KAZNENOM PRAVU}

Danas većina smatra da samo postojanje medicinske indikacije nije dovoljno za isključenje protupravnosti povrede tjelesnog integriteta. Medicinska indikacija ne opravdava intervenciju u tjelesni integritet ili druga osobna dobra pacijenta ako pacijent nije pristao na medicinski zahvat. ${ }^{54} \mathrm{U}$ kaznenom pravu sporno je pitanje isključuje li pristanak oštećenog pacijenta kazneno djelo u njegovoj samoj određenosti u zakonu odnosno u samom biću djela ili, pak, isključuje protupravnost radnje ili propusta.

\section{POREDBENI PRIKAZ KAZNENOPRAVNOG UČINKA PRISTANKA PACIJENTA KAO OŠTEĆENIKA}

U poredbenom kaznenom pravu učinak pristanka na kaznenu odgovornost zdravstvenih radnika, zbog različitih stavova teorije i sudske prakse, razlikuje se ovisno o prihvaćenom stajalištu, primarno o pitanju kojim pravnim dobrima oštećenik uopće može slobodno raspolagati. Također, ne rijetko, u poredbenom zakonodavstvu pronalazimo i odredbe koje uređuju pitanje učinka pristanka, pa tako njemačko kazneno pravo ima opće pravilo po kojemu pristanak žrtve tjelesnog ozljeđivanja isključuje protupravnost, ako to nije protivno javnom interesu. Naime, čl. 228. Kaznenog zakonika SR Njemačke ${ }^{55}$ propisuje da ne čini protupravno djelo onaj tko prouzroči tjelesne ozljede uz pristanak žrtve, osim ako se, unatoč pristanku, krši javni poredak. ${ }^{56}$

Novija teorija općeg dijela njemačkog materijalnog kaznenog prava, koja je prihvaćena za medicinske intervencije, polazi od važnosti pristanka pacijenta. Medicinski zahvati koji su negativno utjecali na fizički integritet pacijenta tretiraju se u njemačkoj kaznenopravnoj teoriji i sudskoj praksi kao tjelesne ozljede. To znači da se sve medicinske intervencije mogu opravdati, u pravilu samo valjanim pristankom pacijenta, za što je nužan uvjet odgovarajuće obavještavanje pacijenta o tijeku, rizicima i alternativnim mogućnostima liječenja. Dakle, moderno njemačko kazneno pravo svaku medicinsku intervenciju smatra potencijalnim kaznenim djelom tjelesne ozljede, čija se protupravnost procjenjuje, usprkos ispravnom tijeku liječenja i lege artis obavljenoj intervenciji, uzimajući u obzir samo postojanje svjesnog i slobodnog informiranog pristanka pacijenta. Drugim riječima, stajalište njemačke teorije i judikature jest tvrdnja da se medicinskim zahvatom doista ostvaruje biće kaznenog djela teške tjelesne ozljede (§ 223-227 KZ), ali je ipak

54 Kennedy, I., Grubb, A., Medical Law, London, 2000., str. 970.

55 Strafgesetzbuch BGBI.I.S 3322 (1998.), 3671 (2013.), 3799 (2013.), 1722 (2015.); dostupno na: http://www.gesetze-im-internet.de/englisch_stgb/englisch_stgb.html\#p0191 i na: http://www.gesetze-iminternet.de/bundesrecht/stgb/gesamt.pdf .

56 Wer eine Körperverletzung mit Einwilligung der verletzten Person vornimmt, handelt nur dann rechtswidrig, wenn die Tat trotz der Einwilligung gegen die guten Sitten verstößt. 
Dr. sc. Nina Mišić Radanović: Pristanak pacijenta na medicinski zahvat kao razlog za isključenje... Zbornik radova Pravnog fakulteta u Splitu, god. 55, 4/2018., str. 865.- 892.

isključena protupravnost zbog pristanka oštećenika (njem. Einwilligung) ${ }^{57}$ Međutim, kada je riječ o pitanju gdje se kazneno djelo čini liječenjem bez valjanog pristanka pacijenta, njemački pravnici nisu jedinstveni, jer jedni smatraju da se radi o djelu protiv tjelesnog integriteta dok se po drugima radi o deliktu protiv osobne slobode. ${ }^{58}$ Zaključno, kaznenopravna procjena medicinskog postupka u njemačkoj doktrini i judikaturi ovisna je samo o valjanosti pristanka pacijenta. ${ }^{59}$ Njemačka legislatura ne propisuje nesavjesno liječenje kao posebno kazneno djelo, a ako su ispunjeni određeni uvjeti, isključena je protupravnost kaznenog djela tjelesne ozljede zbog valjanog i informiranog pristanka oštećenika. ${ }^{60}$ Međutim, u modernoj njemačkoj kaznenopravnoj dogmatici sve veći broj autora smatra da pristanak oštećenika, ako ispunjava određene pretpostavke, uvijek isključuje samo biće kaznenog djela ${ }^{61}$

Slično njemačkom modelu, i članak 90. austrijskog KZ-a (Pristanak ozlijeđenog) propisuje: (1) Tjelesna ozljeda ili ugrožavanje tjelesne sigurnosti nisu protupravni, ukoliko je ozlijeđeni/ugroženi na nju pristao i ukoliko ozljeda (ugroza) kao takva ne krši dobre običaje. (2) Ona od strane liječnika provedena sterilizacija na osobi uz njezin pristanak nije protupravna, ukoliko je, ili osoba već napunila 25 godina života ili zahvat iz drugih razloga ne krši dobre običaje. (3) Ne može se dati pristanak na sakaćenje ili drugu ozljedu genitalija, koja je takva da može prouzročiti dugotrajan utjecaj na seksualni osjet. ${ }^{62}$

I slovensko kazneno zakonodavstvo u čl. 125. Kazenskog zakonika ${ }^{63}$ propisuje da prouzročenje lake tjelesne ozljede nije protupravno ako je oštećenik pristao na to. Prouzročenje teške ili osobito teške tjelesne ozljede nije protupravno ako je oštećenik pristao, a pri tome nisu povrijeđena tuđa prava ili nije protivno

57 Korošec, D., Medicinsko kazensko pravo, Ljubljana, 2016., str. 175.

58 Radišić, J., „Pristanak pacijenta na lečenje i odgovornost zbog lečenja bez punovažnog pristanka“, Evropska revija za pravo osiguranja, 1, 2012., str. 44.

59 Francuska kaznena teorija nije baš tako eksplicitna, ne samo u pogledu postojanja kaznenog djela tjelesne ozljede kao posljedice medicinskih intervencija, nego i učinka pristanka pacijenta na opći pojam kaznenog djela kao ključnog ili glavnog razloga isključenja protupravnosti u medicinskoj djelatnosti. Korošec, D., „Physicians' Rights In Slovenia and Europe (From The Standpoint Of The Law Of Personal Rights)“, Zdrav vestn, 2006., 75, str. 648.

60 Roxin, C., Schroth, U., Medizinstrafrecht, Im Spannungsfeld von Medizin, Ethik und Strafrecht, 2. Aufl., Stuttgard, 2001. i Quas, M., Zuck, R., Medizinrecht, München, Verlag CH Beck, 2008., str. 922. O značenju pristanka para 228. Wer eine Körperverletzung mit Einwilligung der verletzten Person vornimmt, handelt nur dann rechtswidrig, wenn die Tat trotz der Einwilligung gegen die guten Sitten verstößt prinudne norme. Cit. prema Roksandić Vidlička, S., Aktualna pitanja pojedinih kaznenih djela protiv zdravlja ljudi u svjetlu..., str. 116.

61 Tako Roxin, C., Strafrecht, Allgemeiner Teil, Band I, 4. Auflage, München, 2006., str. 544.

62 Cit. prema Roksandić Vidlička, S., Aktualna pitanja pojedinih kaznenih djela protiv zdravlja ljudi u svjetlu..., str. 836. U austrijskom kaznenom, kao i građanskom pravu, mišljenja o problemima liječenja bez pristanka razlikuju se. Austrijski znanstvenici zagovaraju stav da je ispravno liječenje ono koje je izvedeno lege artis, te da se, čak i kada se ono obavlja bez odgovarajućeg pristanka, ne čini kazneno djelo namjernog ozljeđivanja tijela. Stoga bi medicinski postupci kojima je cilj poboljšati zdravlje pacijenta, sa stanovišta medicinske struke, trebali biti isključeni od kažnjavanja za tjelesne ozljede. Rijavec, V., Gorišek, J., Flis, V., „Discussing medicine and law in Maribor“, Acta medico-biotechnica, 2011., 4, 1, str. 13.

63 Kazenski zakonik Slovenije, uradno prečiščeno besedilo (KZ-1-UPB2), Uradni list RS, št. 50/2012 z dne 29. VI. 2012., dostupno na https://www.uradni-list.si/1/content?id=109161\#!/Kazenski-zakonik. 
općepriznatim pravnim vrijednostima. Primjerice, operacija lica kojom se mijenja identitet ili odstranjivanje kože na prstima koje onemogućuje uzimanje otisaka i sl. protivno je pravnim vrijednostima i/ili bi moglo dovesti do povrede tuđih prava. ${ }^{64}$

Posebno je značajna odredba st. 3. istog članka Kazenskog zakonika Slovenije koja se odnosi isključivo na namjerno nanošenje teške ili osobito teške tjelesne ozljede u liječenju ili djelatnosti u svrhu liječenja, koje nije protupravno ako je pristanak dan u obliku i pod uvjetima predviđenima zakonom. ${ }^{65}$ Također, ako je ozlijeđeni tijekom počinjenja djela teške ili osobito teške tjelesne ozljede ranije dani pristanak povukao, to neće utjecati na isključenje protupravnosti postupanja iz prethodnog stavka. U slučajevima propisanima u stavku drugom ovoga članka, počinitelj koji je nakon povlačenja pristanka započeo djelovanje neće se kazniti za pokušaj ili za dovršeno lakše djelo obuhvaćeno pokušajem težeg kaznenog djela. ${ }^{66}$

Poseban ekskulpacijski učinak pristanka propisan je u Kazenskom zakoniku Slovenije i kod kaznenog djela nepružanja zdravstvene pomoći u članku 178. st. 2. jer je isključena protupravnost ako liječnik ili drugi zdravstveni radnik ne poduzme određenu vrstu liječenja, zahvat ili drugi medicinski postupak na izričit pisani zahtjev pacijenta ili druge osobe koja je sposobna donositi odluke o sebi i koja pomoć odbija, čak i onda kada je obaviještena o nužnosti pomoći i mogućim posljedicama odbijanja, i nakon što ju je liječnik ponovno pokušao nagovoriti da promijeni svoju odluku. ${ }^{67}$

Dakle, slovensko kazneno zakonodavstvo pristanku oštećenika daje učinak općeg, a pristanku pacijenta i posebnog razloga isključenja protupravnosti kod kaznenih djela tjelesne ozljede i nepružanja medicinske pomoći. Ali, istovremeno slovensko kazneno pravo ipak poznaje i posebno kazneno djelo nesavjesnog liječenja, koje se očigledno procjenjuje po drugim kriterijima.

64 Izključitev kaznivega dejanja pri telesnem poškodovanju s soglasjem poškodovanca (125. člen):

(1) Povzročitev lahke telesne poškodbe (122. člen) ni protipravna, če je poškodovanec privolil vanjo. V tem primeru se pri mladoletni ali slabotni osebi upošteva privolitev, če jo v skladu z zakonom v skrbi za njuno zdravje da tisti, ki zastopa take osebe.

(2) Naklepna povzročitev hude (123. člen) ali posebno hude (124. člen) telesne poškodbe ni protipravna, če je poškodovanec privolil vanjo in pri tem niso bile prizadete koristi koga drugega ali ogrožena kakšna skupna pravna vrednota.

65 (3) Ne glede na prejšnji odstavek naklepna povzročitev hude ali posebno hude telesne poškodbe pri zdravljenju ali zdravilski dejavnosti ni protipravna, če je bila privolitev dana v obliki in ob pogojih, ki jih določa zakon.

${ }^{66}$ (4) Če je poškodovanec med storitvijo kaznivega dejanja hude ali posebno hude telesne poškodbe prej dano privolitev preklical, to na izključitev protipravnosti dejanj po prejšnjem odstavku ne vpliva, $v$ drugih primerih po drugem odstavku tega člena pa se storilec, ki začetega dejanja po preklicu ni dokončal, ne kaznuje za njegov poskus oziroma se ne kaznuje za dokončano lažje dejanje, zajeto v poskusu hujšega kaznivega dejanja.

67 Opustitev zdravstvene pomoči (178. člen)

(1) Zdravnik ali drug zdravstveni delavec, ki v nasprotju s svojo poklicno dolžnostjo ne pomaga bolniku ali komu drugemu, ki je v nevarnosti za življenje, se kaznuje z zaporom do enega leta.

(2) Dejanje iz prejšnjega odstavka ni protipravno, če zdravnik opusti določen način zdravljenja, poseg ali medicinski postopek na izrecno pisno zahtevo bolnika ali druge osebe, ki je sposobna odločati o sebi in pomoč zavrača tudi še potem, ko je poučena o nujnosti pomoči ter o mogočih posledicah zavrnitve in tudi potem, ko jo je zdravnik ponovno poskusil prepričati, naj spremeni svojo odločitev. 
Dr. sc. Nina Mišić Radanović: Pristanak pacijenta na medicinski zahvat kao razlog za isključenje... Zbornik radova Pravnog fakulteta u Splitu, god. 55, 4/2018., str. 865.- 892.

I švedsko kazneno zakonodavstvo sadrži odredbu o učinku pristanka oštećenika koji pod određenim uvjetima predstavlja opći razlog isključenja odgovornosti. ${ }^{68}$

Neke države koje pripadaju tzv. njemačkom modelu kažnjavanja za medicinske pogreške, u kojemu nije propisano posebno kazneno djelo nesavjesnog liječenja, ipak propisuju samovoljno liječenje kao posebno kazneno djelo protiv slobode čovjeka. ${ }^{69}$ Tako je u čl. 110. austrijskog KZ-a (Eingenmächtige Heilbehandlung) propisano kažnjavanje za onoga tko drugoga liječi bez njegova pristanka, čak i ako je liječenje bilo prema pravilima medicinske znanosti. ${ }^{70}$

Suprotna teorijska stajališta polaze od toga da je pristanak pacijenta kod medicinskih zahvata ekskulpacijski učinkovit samo ako udovoljava interesu države zbog kojeg ona vodi kazneni postupak. Drugim riječima, da bi pristanak pacijenta imao učinak isključenja protupravnosti mora oduzeti radnji/propustu zdravstvenog radnika antisocijalni karakter, tj. suglasnost žrtve mora predstavljati suglasnost zajednice. ${ }^{71}$ Stoga, premda je pacijent dao pristanak, nije isključena protupravnost za postupke zdravstvenih radnika kojima se ugrožavaju javno dobro i javni interes. Tako, pacijentov pristanak odnosno zahtjev liječniku ili drugom medicinskom radniku za aktivnu eutanaziju ne isključuje protupravnost takvog usmrćenja, jer je održavanje života javni interes te bi svaki zdravstveni radnik odgovarao za kazneno djelo ubojstva. Dakle, pristanak oštećenika u ovim sustavima isključuje protupravnost samo kod individualnih dobara kod kojih autonomija pojedinca nije u sukobu s društvenim interesima, pa je općeprihvaćen stav i teorije i judikature da ne postoji kazneno djelo u slučaju nanošenja lake tjelesne ozljede prilikom vađenja krvi, rezanja ili brijanja dlaka, vađenja zuba i sl. U tim slučajevima načelo volenti non fit iniuria isključuje protupravnost takvih zahvata, ako je pacijent na zahvat pristao i ako je pristanak valjan. Međutim, premda pristankom na pojedini medicinski zahvat pacijent ipak preuzima rizik i za sam ishod zahvata, on ne snosi

68 Swedish Penal Code was adopted in 1962 and entered into force on 1 January 1965. Section 7. Chapter 24, On General Grounds for Exemption from Criminal Responsibility: An act committed by a person with the consent of some other person towards whom it is directed, constitutes a crime only if the act, having regard to the injury, violation or danger which it involved, its purpose, and other circumstances, is indefensible.

U Italiji je Zakonom 189/2012 od 8. studenog 2012. godine izvršena dekriminalizacija radnje/ propusta liječnika kojom je uslijed tzv. obične nepažnje (culpa levis) prouzročena tjelesna ozljeda ili usmrćenje. Sire Vergalo, M. G., Frati, P., Busardo`, F. P., Matteo, G., Zaani, S., Ciancolini, G., Correnti, F. R., Di Luca, N. M., ,The legislative reform of medical liability in Italy and the decriminalization of slight negligence: controversial issues“", Prevention \& Research, 2, 2, 2013., str. 67.

${ }^{69}$ U njemačkoj kaznenopravnoj teoriji, različito od judikature, prevladava stav po kojemu liječenje bez valjanog pristanka predstavlja delikt protiv osobne slobode, jer se samovoljnim zahvatom koji je medicinski indiciran i obavljen lege artis, ipak povređuje jedino pacijentova autonomija ili sloboda odlučivanja kao temeljno pravo čovjeka, a ne njegov tjelesni integritet. Laufs, A., Uhlenbruck, W., Handbuch des Arztrechts, str. 1229-1230.

70 Wer einen anderen ohne dessen Einwilligung, wenn auch nach den Regeln der medizinischen Wissenschaft, behandelt, ist mit Freiheitsstrafe bis zu sechs Monaten oder mit Geldstrafe bis zu 360 Tagessätzen zu bestrafen. StGB-Strafgesetzbuch, dostupno na: https://www.jusline.at/gesetz/stgb/ paragraf/110, Hofmann, J., Ausgewählte Probleme der Eigenmächtigen Heilbehandlung im Rettungsdienst, 2017., dostupno na: https://www.oegern.at/wp/wp-content/uploads/.

${ }^{71}$ „Consent is effective only if its existence sufficiently satisfies the state's interests in making the conduct criminal ". Hughes, G., op. cit., str. 234. 
rizik od medicinske pogreške, pa ako je počinjena pogreška tijekom liječenja, protupravnost nije isključena. Drugim riječima, pristanak pacijenta odnosi se samo na intervenciju provedenu lege artis jer se pacijent zapravo nikada ne suglašava s povredom koja bi nastala uslijed medicinske pogreške. ${ }^{72}$

U novom francuskom kaznenom pravu medicina i dalje uživa određeni poseban status, ali pristanak pacijenta predstavlja samo jedan od četiriju kumulativnih uvjeta za isključenje protupravnosti medicinske intervencije. Naime, uz pristanak, zahtijevaju se još i potrebna medicinska kvalifikacija počinitelja, svrha intervencije i tehnička ispravnost medicinskog postupka. ${ }^{73}$

Poredbeni prikaz ukazuje na to da je u Europi više prihvaćen pristup po kojemu procjena medicinskih intervencija proizlazi iz suglasnosti pacijenta kao, više ili manje, nužnog uvjeta za isključenje protupravnosti, prije svega tjelesnih ozljeda. Unatoč tome što francuska teorija čini upitnim učinak oštećenikove volje na opći pojam kaznenog djela, suprotno, njemačka sudska praksa i veći dio kaznenopravne teorije pacijentov pristanak nesumnjivo smatra ključnim odnosno glavnim razlogom isključenja protupravnosti medicinske intervencije. ${ }^{74}$

\section{PRISTANAK PACIJENTA U HITNIM MEDICINSKIM SLUČAJEVIMA}

Medicinski su hitna ona stanja kod kojih bi zbog nepružanja liječničke pomoći mogle nastati trajne štetne posljedice po zdravlje ili po život bolesnika. Neodgodiva medicinska intervencija je ona zbog čijeg bi nepoduzimanja bio neposredno ugrožen život pacijenta ili bi mu prijetila ozbiljna i neposredna opasnost od težeg oštećenja njegova zdravlja. ${ }^{75}$

Problem koji se pojavljuje u hitnim slučajevima predstavlja upravo liječenja bez pristanka pacijenta odnosno pitanje odgovornosti zdravstvenog radnika u slučaju kada pacijent nije u mogućnosti izjaviti pristanak na medicinski zahvat zbog hitnog stanja. Kada liječnici/zdravstveni radnici mogu poduzeti medicinske intervencije bez pristanka pacijenta, a da time ne čine kazneno djelo? Iz perspektive liječnika, sva pitanja pristanka pacijenta mogu biti pojednostavljena do samo jednog upita: „Smijem li liječiti ovog pacijenta?“, ali, odgovor, ponekad nije tako jednostavno pronaći. ${ }^{76} \mathrm{U}$ ovim slučajevima zdravstveni radnici mogu se naći u procjepu između

72 Protivno, dio njemačke pravne literature upućuje na dvostruku prirodu pristanka pacijenta na predloženu medicinsku intervenciju te pristanak nije samo osnova opravdanja za povredu tijela, već istovremeno i suglašavanje s neizbježnim rizicima samoga zahvata. Deutsch, E., Medizinrecht-Arztrecht, Arztneimittelrecht, Medizinprodukterecht und Transfusionsrecht, Berlin, 2003., str. 77.

73 Korošec, D., Pravice zdravnikov v Sloveniji in Evropi (osebnostnopravni..., str. 648.

74 Šire o razlici između francuskog i angloameričkog pristupa Hughes, G., op. cit., str. 247.

75 Čl. 18. st. 3. Zakona o liječništvu (NN br. 121/03. i 117/08.) i čl. 16. st. 1. ZZPP-a.

76 Peters, C., Consenting to medical treatment: legal requirements vs medical practice. Are healthcare providers exposing themselves to potential legal action?, NZMJ, 7 August 2009, vol. 122, no. 1300, str. 50. Dostupno na: http:/www.nzma.org.nz/journal/122-1300/3734/. 
dužnosti pružanja medicinske pomoći i dužnosti traženja pristanka pacijenta, pa se procjena njihove odgovornosti vrši sukladno pravnom uređenju prisilnog liječenja i primjene hitnog medicinskog tretmana bez pristanka.

Općeprihvaćeno je pravilo da liječnik/zdravstveni radnik može djelovati bez pristanka pacijenta, jer bi otkazivanje medicinskog postupka, dok se ne dobije pristanak, rezultiralo štetom za pacijenta. ${ }^{77} \mathrm{Ne}$ postoji odgovornost zdravstvenih radnika za neodgodive medicinske intervencije koje bi spriječile ugrožavanje/ povredu života i zdravlja pacijenta ili trajno oštećenje zdravlja. Tako, primjerice, ako je osoba dovedena u bolnicu bez svijesti, liječnik neće odgovarati za operativni zahvat nužan za spašavanje života te osobe..$^{78}$ Drugim riječima, medicinsko postupanje bez valjanog pristanka pacijenta smije se poduzeti u slučajevima hitnje, kada je liječenje, kirurški ili drugi medicinski zahvat poduzet prema osobi koja nije pri svijesti ili je nesposobna za rasuđivanje, a nije dostupan član uže obitelji, zakonski zastupnik, skrbnik ili osoba od povjerenja, a odgodom liječenja ili zahvata bio bi ugrožen njezin život ili bi došlo do znatnog pogoršanja njezina zdravlja. ${ }^{79}$ Dakle, hitna medicinska intervencija jasno ograničava pravo informiranog pristanka pacijenta, ali samo dok traje navedena opasnost te se mogu poduzimati samo oni medicinski postupci koji su nužni za otklanjanje opasnosti za život i zdravlje osobe.

Normativni okvir nedvojbeno ukazuje na to da liječnik/zdravstveni radnik uvijek mora nastojati dobiti pristanak u svim situacijama, pa i u onim hitnim. Drugim riječima, zdravstveni radnik mora poduzeti svaki razuman napor da odredi što bi zapravo sam pacijent želio. No, ukoliko se radi o vitalnoj medicinskoj intervenciji, a pristanak se ne može dobiti ili pacijent odbija dati pristanak, liječnik ipak treba učiniti taj zahvat. Naime, u hitnim stanjima dolaze do primjene načelo neškodljivosti i načelo dobročinstva te liječnik, obavljajući svoj humani poziv, može štititi ljudsko zdravlje i život kao najveće ljudsko dobro i bez pristanka. Dakle, nužna medicinska pomoć obveza je liječnika/zdravstvenog radnika i u slučajevima kada pacijent nije sposoban odlučivati o samom sebi ili kada pristanak ne bi bilo moguće dobiti u razumnom vremenu te kada je medicinski zahvat u najvećoj mjeri u zdravstvenu korist pacijenta. Štoviše, liječnik i drugi zdravstveni radnik obvezni su intervenirati u hitnim stanjima jer, u protivnom, čine kazneno djelo nepružanja medicinske pomoći ${ }^{80}$

77 Faden, R. R., Beauchamp, T. L., A History and Theory of the Informed Consent, New York, 1986. str. 36. Cit. prema Gazdek, D., op . cit., str. 75. Također, čl. 8. Bioetičke Oviedo Konvencije navodi ako se zbog hitne situacije ne može dobiti odgovarajući pristanak, bilo koji medicinski nužan zahvat može se provesti odmah u korist zdravlja dotičnog pojedinca. Dakle, hitnost intervencije isključuje pacijentov pristanak samo ako on nije sposoban izjaviti da odbija medicinski zahvat.

78 Protivno je načelu nepovredivosti fizičkog integriteta poduzimanje operativnog zahvata na nekoj osobi protiv njene volje, pa i onda kad bi to bilo od koristi za nju, osim ako ne pretežu posebni razlozi koji opravdavaju takav postupak kao što je životna opasnost. Mujović-Zornić, H., Petrović, Z., „Odgovornost zdravstvenih ustanova za štete kao posledice lečenja (Responsibility of medical institutions for damages resulting from treatment)", Vojnosanit Pregl, 2012., 69(8), str. 696.

79 Čl. 18. ZZPP-a.

80 Tako i Gazdek, D., op. cit., str. 77. 
Međutim, ovdje se teorijski otvara pitanje je li temelj nekažnjivosti isključenje protupravnosti ili, pak, pretpostavljeni pristanak. Postupak zdravstvenog radnika u hitnim situacijama, koji je zapravo poduzeo samovoljno liječenje odnosno liječenje bez valjanog pristanka pacijenta, može se u kaznenom pravu tretirati kao slučaj krajnje nužde (opravdavajuće ili ispričavajuće). Također, postojanje životnih situacija, npr. razni hitni zahvati (prekid trudnoće i sl.) kada pacijent nije mogao dati pristanak, opravdava onaj krajnji pozitivni učinak za pacijenta u specifičnoj situaciji koja nameće hitnu, neodgodivu intervenciju, pa se pretpostavlja njegov pristanak. Time je prihvaćeno stajalište da se bilo koji medicinski nužan zahvat može provesti odmah u korist zdravlja dotičnog pojedinca ${ }^{81}$ Premda ova situacija počiva na ideji pretpostavljenog pristanka ili pretpostavke o pristanku (u skladu s parafraziranom sintagmom in dubio pro vita), poduzimanje hitne medicinske mjere redovno se poklapa sa stanjem neposredne opasnosti, koja se, u pravilu, opravdava institutom krajnje nužde. Ovaj oblik pomoći u nuždi teorijski otvara pitanje potrebe da se slične situacije uopće razmatraju izvan okvira krajnje nužde i na kraju čine upitnim opravdanost izdvajanja pretpostavljenog pristanka kao samostalnog razloga za nekažnjavanje. ${ }^{82}$ Pod uvjetom da je medicinsku intervenciju liječnik obavio u skladu s pravilima medicinske struke, u ovakvim je situacijama isključena protupravnost, jer su ostvareni svi uvjeti za postupanje u krajnjoj nuždi. ${ }^{83}$

Ali, većina u teoriji i sudskoj praksi pretpostavljeni pristanak prihvaća kao poseban razlog isključenja protupravnosti. ${ }^{84}$ Dokazivanje hipotetičkog pristanka značajno se razlikuje u kaznenoj i građanskoj odgovornosti. U parničnom postupku liječnik/zdravstveni radnik koji ističe prigovor postojanja hipotetičkog pristanka snosi teret dokazivanja dok u kaznenom postupku načelo in dubio pro reo djeluje u korist zdravstvenog radnika, jer se u sumnji polazi od pretpostavke da bi u slučaju urednog obavještavanja pacijent dao svoj pristanak..$^{85}$

${ }^{81}$ Američka sudska praksa načelno je zauzela stav da se, ako je vitalno ugrožen pacijentov život, pretpostavlja postojanje pacijentova pristanka u situacijama u kojima liječnik djeluje bez pristanka. Međutim, ta ista judikatura u jednom je slučaju zauzela stav kako pacijent može odbiti operaciju amputacije noge zbog gangrene, premda bi se tom operacijom spasio njegov život. Time je priznato da je pravo na odbijanje, osobe koja je svjesna i sposobna za odlučivanje, jače pravo nego pravo da se bez pristanka djeluje u hitnim intervencijama. Hartman, K. M., Liang, A. B., „Exception to Informed Consent in Emergency Medicine", Hospital Physician, 1999., 35, str. 54. Dostupno na: http://www.turner-white. com/pdf/hp_mar99_emergmed.pdf.

82 Vuković, I., op. cit., str. 58.

83 Kazneno djelo neće postojati ni onda kada liječnik na povrijeđenome bez njegova pristanka poduzme kirurški zahvat, ali ne uspije spasiti njegov život, jer ni u tom slučaju učinjeno zlo nije veće od zla koje je prijetilo. Tako Tomić, Z., op. cit., str. 223.

${ }^{84}$ Ovakav stav u hrvatskoj starijoj teoriji zastupao je Franjo Bačić. Bačić, F., Krivično pravo. Opći dio, Zagreb, 1986., 3. izdanje, str. 229. Sudska praksa koristila je pojam pristanka bolesnika puno prije nego li je on unesen u zdravstveno zakonodavstvo. Tako je u odluci od 23. veljače 1967. godine Vrhovni sud RH zauzeo stajalište da ,zadiranje u tjelesni integritet određene osobe od strane treće stručne osobe u svrhu liječenja gubi karakter protupravnosti jedino uz prethodni pristanak bolesne osobe, a bez pristanka samo onda ako se takva osoba nalazi u stanju u kojem je nesposobna izraziti takav pristanak, a to stanje bez hitne liječničke intervencije predstavlja očiglednu opasnost za život ili zdravlje osobe". Cit. Turković, K., Pravo na odbijanje medicinskog tretmana u Republici Hrvatskoj, str. 163.

85 Novija francuska građanskopravna sudska praksa u pitanju tereta dokazivanja postojanja pristanka pacijenta usvaja rješenje Kasacijskog suda (Cour de Cassation) kako teret dokazivanja da je pacijent bio 
Prigovor hipotetičkog ili uvjetnog pacijentovog pristanka (ili pozivanje na pravovaljano alternativno postupanje) čest je u slučajevima odgovornosti zbog povrede obveze da se pacijenta obavijesti o rizicima zahvata. Naime, njemački liječnici i zdravstvene ustanove brane se tvrdnjom da bi pacijent pristao na zahvat da je bio uredno obaviješten. ${ }^{86} \mathrm{U}$ tom je smislu i Vrhovni sud RH zauzeo stav da je nedopustivo i protivno načelu nepovredivosti fizičkog integriteta vršenje operativnog zahvata na nekoj osobi protiv njene volje, pa i u slučaju kad bi to bilo od koristi za tu osobu, osim ako ne pretežu posebni razlozi koji opravdavaju takav postupak kao što je životna opasnost i stanje bolesnika zbog kojeg on nije u mogućnosti dati svoj pristanak. ${ }^{87}$ Međutim, nikako ne bi bilo prihvatljivo isključenje protupravnosti na temelju pretpostavljenog pristanka, ako odlučivanje dopušta odlaganje bez rizika štete/povrede za pacijenta. ${ }^{88}$

\section{UČINAK PRISTANKA PACIJENTA NA MEDICINSKI ZAHVAT U HRVATSKOM KAZNENOM PRAVU}

Suprotno građanskom obveznom zakonodavstvu, hrvatsko kazneno zakonodavstvo pristanku oštećenika kao razlogu isključenja protupravnosti uopće ne posvećuje pažnju, osim u opisima onih kaznenih djela u kojima (ne)pristanak predstavlja obilježje djela. Stoga ga i kaznena judikatura ne primjenjuje kao opći razlog isključenja protupravnosti nego isključivo utvrđuje njegovo postojanje u konkretnom kaznenom djelu čije je on obilježje, primjerice postoji li pristanak darivatelja kod uzimanja organa ili je li izvršen spolni odnošaj bez pristanka.

Obavljanje medicinske djelatnosti u hrvatskom kaznenom pravu ne predstavlja poseban razlog isključenja protupravnosti, pa se pitanje odgovornosti za provedeno liječenje i zdravstvenu skrb rješava isključivo na razini bića kaznenog djela. Stoga, pristanak/suglasnost pacijenta na medicinsku intervenciju isključuje biće kaznenog djela nesavjesnog liječenja (samovoljnim liječenjem), ali nema nikakva utjecaja na ocjenu je li medicinski postupak bio i protupravan te je li liječnik ili drugi zdravstveni radnik ostvario obilježja kaznenog djela nesavjesnog liječenja. ${ }^{89}$ Štoviše, za neke medicinske zahvate kažnjava se unatoč izričitom i ozbiljnom pristanku pacijenta,

informiran leži na bolnici, a ne na pacijentu. Suprotno, belgijski sudovi usvajali su rješenje po kojemu pacijent mora dokazati da nije dobio dovoljno informacija potrebnih za svoj informirani pristanak. Šire Callens, S., „Medical Civil Liability in Belgium. Four Selected Cases“, European Journal of Health Law, 1, 2003., str. 125.

86 Tako Radišić, J., Dužnost lekara da.... str. 42.

87 VSRH 1554/74, ZSO, knj. 1., sv. 4, str. 204.

${ }_{88}$ Tako, prema odluci strane judikature, s pravom nije isključena protupravnost sterilizacije učinjene tijekom poroda carskim rezom, na temelju procijenjenog rizika da bi neki budući porođaj mogao ugroziti život žene. Kako između aktualnog i nekog kasnijeg poroda slijedi odgovarajući vremenski period u kojem je moguće utvrditi stvarnu volju žene, izostalo stanje nužde ne opravdava propuštanje da se mišljenje žene na valjan način pribavi. Vuković, I., op. cit., str. 54.

${ }^{89}$ Novoselec, P., Bojanić, I., op. cit., str. 209. 
jer predstavljaju kaznena djela, primjerice usmrćenje na zahtjev, protupravni prekid trudnoće, sakaćenje koje nije medicinski indicirano i dr.

Dakle, pristanak pacijenta na medicinsku intervenciju ne predstavlja ništa drugo nego samo jedan u nizu uvjeta za poduzimanje medicinskog zahvata ili, drugim riječima, pristanak pacijenta na medicinski zahvat nije samostalan razlog isključenja protupravnosti nego samo jedan od uvjeta njegove dopuštenosti u konkretnom slučaju.

U legislativi i sudskoj praksi postoji ozbiljan previd kada je u pitanju suština pristanka pacijenta na medicinsku intervenciju, a o razlici između pristanka pacijenta i postupanja na vlastiti rizik gotovo se uopće ne vodi računa, pa se u praksi svako dobrovoljno podvrgavanje pacijenta medicinskoj intervenciji podvodi pod pristanak pacijenta. Ako je danas pristanak pacijenta na medicinsku intervenciju jedan od pravnih standarda, on bi svakako trebao biti informiran, u smislu svih postavljenih pravnih zahtjeva. Da bi pristanak pacijenta kao oštećenika imao pravni učinak, nužno je najprije da ispunjava uvjete valjanosti potrebne za bilo koji pristanak. Međutim, ono što se danas prakticira u našim zdravstvenim ustanovama, na jednostavnim obrascima koji, doslovno u dvije crte, sadrže ime pacijenta i naziv medicinske mjere koja će se poduzeti (pretrage, zahvata i dr.), nikako se ne može nazvati valjanim informiranim pristankom nego pukom suglasnošću pacijenta. ${ }^{90}$

\section{ZAKLJUČAK}

Učinak pristanka pacijenta na medicinski zahvat u medicinskom pravu još uvijek je upitan zbog nejasnih, neujednačenih i nekonzistentnih propisa. Općenito, različiti učinak pristanka oštećenika u građanskom i kaznenom pravu posljedica je činjenice da država u kaznenim slučajevima ima interese koji ne postoje u građanskim predmetima.Takav je interes, primjerice, očuvanje zdravlja građana. Građanski delikt uključuje interese samo dviju stranaka pred sudom te je samo bitno je li tužitelj pretrpio ozljedu zbog koje tuženik mora naknaditi štetu, pa ako je tužitelj zapravo pristao na povredu, postoji malo razloga da ga tuženik obešteti. Dakle, pristanak pacijenta može imati dvostruku pravnu prirodu i funkciju: može biti razlog isključenja protupravnosti, ali i jedan specifičan pravni posao.

U kaznenom pravu nije zauzet takav nedvojben stav o učinku pristanka oštećenika te se u nedostatku legislative te u uvjetima neujednačenih propisa, poseže za komparativnom analizom kaznenih zakona i sudske prakse. U tom području postoje dva teorijska i normativna stajališta. Prvo usvaja njemačko kazneno zakonodavstvo, koje sadrži opće pravilo da pristanak žrtve tjelesnog ozljeđivanja isključuje protupravnost, ako to nije protivno javnom interesu te slovensko kazneno zakonodavstvo koje isključuje protupravnost prouzročenja lake tjelesne ozljede, ako

90 Usp. Pichler, D., „Obaviješteni pristanak u obrascima suglasnosti kojima se prihvaća preporučeni dijagnostički odnosno terapeutski postupak Kliničkog bolničkog centra Osijek i njihova usklađenost s propisima i međunarodnom praksom“, Pravni vjesnik, god. 30, br. 1, 2014., str. 89-114. 
je oštećenik pristao na to. Prouzročenje teške ili osobito teške tjelesne ozljede nije protupravno ako je oštećenik pristao, a pri čemu nisu povrijeđena tuđa prava ili nije protivno općepriznatim pravnim vrijednostima. Uz to, slovenski je zakonodavac riješio status obavljanja liječničke profesije tako što namjerno nanošenje teške ili osobito teške tjelesne ozljede u liječenju ili djelatnosti u svrhu liječenja nije protupravno, ako je pacijent dao pristanak u obliku i pod uvjetima predviđenima zakonom. Također, poseban ekskulpacijski učinak odbijanja davanja pristanka propisan je i kod kaznenog djela nepružanja zdravstvene pomoći, jer nema djela, ako liječnik ne poduzme određenu vrstu liječenja, zahvat ili drugi medicinski postupak na izričit pisani zahtjev pacijenta ili druge osobe. Dakle, slovensko kazneno zakonodavstvo pristanku oštećenika daje učinak općeg, a pristanku pacijenta i posebnog razloga isključenja protupravnosti kod kaznenih djela tjelesne ozljede i nepružanja medicinske pomoći dok njemačka sudska praksa i veći dio teorije pacijentov pristanak smatra glavnim razlogom isključenja protupravnosti medicinske intervencije.

Drugo teorijsko stajalište polazi od toga da pristanak pacijenta kod medicinskih zahvata ima ekskulpacijski učinak samo ondje gdje država nema interes za vođenje kaznenog postupka. Stoga, ne postoji kazneno djelo u slučaju nanošenja lake tjelesne ozljede prilikom vađenja krvi, brijanja dlaka, vađenja zuba i sl.

Zbog postojanja različitih pristupa o pitanju isključenja protupravnosti radnji u obavljanju medicinske profesije, u kaznenom je pravu potreban, teorijski i normativno, nesporan i argumentiran stav o ulozi volje pacijenta na isključenje odgovornosti liječnika/zdravstvenih radnika za tjelesne ozljede ili druga djela na štetu pacijentove osobnosti. Naime, zdravstvenim radnicima dobro zdravlje predstavlja krajnju vrijednost, a individualna sloboda izbora samo je sredstvo za ispunjenje te svrhe, dok je pravnicima krajnja vrijednost osobna autonomija pacijenta. ${ }^{91}$

Stoga bi se de lege ferenda moglo razmisliti o usvajanju posebnog tretiranja pristanka pacijenta na medicinske intervencije i to pristupom koji je sadržan u njemačkom i slovenskom kaznenom zakonodavstvu. Time bi bilo riješeno i sporno pitanje učinka prava pacijenta na odbijanje predloženog medicinskog zahvata kao druge strane prava na pristanak. Naime, odbijanje davanja pristanka na liječenje predstavlja vrlo delikatnu situaciju za liječnike/zdravstvene radnike koji, ako nastupi neželjena posljedica, mogu odgovarati, ovisno o tome jesu li poduzeli liječenje ili ne, ili za nesavjesno ili za samovoljno liječenje ili nepružanje hitne medicinske pomoći. Proturječna i dvojbena pravna regulativa čini ovo pitanje učinka odbijanja pacijenta na kaznenu odgovornost liječnika još složenijom, posebno u slučajevima određenih kategorija ranjivih osoba, primjerice djece. Dakle, kako u hrvatskom kaznenom zakonodavstvu ne postoji poseban ekskulpacijski razlog za isključenje protupravnosti kod kaznenog djela nepružanja medicinske pomoći, i ovo bi pitanje bilo poželjno riješiti de lege ferenda. Također, u našem kaznenom i građanskom zakonodavstvu postoji normativna praznina koja se tiče anticipiranih punomoći u

91 Dickens, M. B., „Patients'Interests and Clients'Wishes: Physicians and Lawyers in Discord“, L. Med. \& Health Care, 1987.-1988, 15, str. 112. 
području medicine. Naime, osim u području zaštite osoba s duševnim smetnjama, ne postoje odgovarajuća zakonska rješenja koja bi uredila posebne pretpostavke valjanosti danih naredbi/punomoći u pogledu njihova sadržaja, oblika registracije, vremenskog ograničenja trajanja i dr.

\section{Literatura}

ADAMS, D. C., „Consent to medical treatment of a minor under the Family Code“, Baylor L. Rev., 27, 1975., str. 319-330.

APPELBAUM, S. P., „Assessment of Patients' Competence to Consent to Treatment“, N Engl J Med 2007, 357: str. 1834-1840. Dostupno na: http://www.nejm.org/doi/full/10.

BAČIĆ, F., Krivično pravo, opći dio, Zagreb, 1980., str. 546.

BAGIĆ, S., „Informirani pristanak u sudskoj praksi“, Zbornik radova, 2. Hrvatski simpozij medicinskog prava, Vodice, 2016., str. 255-277.

BAÜMANN, J., Strafrecht, Allgemeiner Teil, 6th ed., 1974.

BEVANDA, M., ČOLAKOVIĆ, M., „Pravo pacijenta na obaviještenost i pristanak i pravne posljedice liječenja bez pristanka pacijenta“", Zbornik radova Aktualnosti građanskog i trgovačkog zakonodavstva i pravne prakse br. 7, Mostar, 2009., str. 200-202.

BOILĂ, R. L., ,Respect for Human Dignity. Ethical and Legal Reflections Regarding the Breach of the Obligation to Inform the Patient", Postmodern Openings, 2013., vol. 4, Iss. 1, March, str. 39-54. Dostupno na: http://postmodernopenings.com.

BOLLWEG, H. G., Defining the extent of (medical) liability, The ever-growing challenge of medical liability: national and European responses, Conference, Strasbourg, 2008.

BOŠKOVIĆ, Z., „Prava pacijenata na primjerenu obaviještenost i odlučivanje“, Informator, br. 5343, od 21. svibnja 2005.

BURKLE, M. C., MUELLER, S. P., SWETZ, M. K., CHRISTOPHER HOOK, C. C., KEEGAN, T. M., ,Physician perspectives and compliance with patient advance directives: the role external factors play on physician decision making", BMC Medical Ethics 2012, 13-31. Dostupno na: http://www.biomedcentral.com/1472-6939/13/31.

CALLENS, S., „Medical Civil Liability in Belgium. Four Selected Cases“, European Journal of Health Law, 1, 2003., str. 115-133.

CANTRELL, C., „A Physician's Liability for Experimental Procedures“, Med Law, 1984., 3, 339-344.

CRNIĆ, I., „Odštetna odgovornost liječnika i zdravstvenih ustanova s prikazom sudske prakse“, Hrvatska pravna revija, veljača 2009., str. 28-41.

ČIZMIĆ, J., „Pravo pacijenata na obaviještenost, s posebnim osvrtom na zaštitu tajnosti podataka o zdravstvenom stanju pacijenta“, Zbornik Pravnog fakulteta Sveučilišta u Rijeci, vol. 29, br. 1, 2008.

DAMAŠKA, M., „Neki krivičnopravni aspekti liječničkih zahvata“, Hrestomatija hrvatskog medicinskog prava, Pravni fakultet, Zagreb, 2016., str. 72-80. 
DE BORD, J., Informed Consent, dostupno na: https://depts.washington.edu/bioethx/.

DE PALMA, A., „Conoscenza, errori, comunicazione con il paziente e consenso consapevole (Knowledge, mistakes, communication with patients and informed consent)“, Italian Journal of Medicine, 2013., 3(1), str. 67-71.

DEUTSCH, E., Medizinrecht-Arztrecht, Arztneimittelrecht, Medizinprodukterecht und Transfusionsrecht, Berlin, 2003.

DIAS PEREIRA, G. A., Existing challenges in medical liability: causation, burden of proof and informed consent. The ever-growing challenge of medical liability: national and European responses, Conference, Strasbourg, 2-3 June 2008, Council of Europe, 2009., str. 141-146.

DICKENS, M. B., „Patients' Interests and Clients' Wishes: Physicians and Lawyers in Discord“, L. Med. \& Health Care, 1987-1988, 15, str. 110-117.

DROBAC, A. J., GOODENOUGH, R. O., „Exposing The Myth Of Consent“, INDIANA HEALTH LAW REVIEW, vol. 12, 2 , 2015, str. 471-531. Dostupno na: ttps://journals.iupui. edu/.

ELLIOTT, C., ,Patients doubtfully capable or incapable of consent“, Kuhse, H., Singer, P. (ed.), A Companion to Bioethics, 2001, str. 452-462.

GAZDEK, D., Informirani pristanak: korijeni, svrha, primjena i ograničenja, Split, 2013. str. 128.

GEERDS, F., Einwilligung und Einverständnis des Verletzten, 1953.

HALLINAN, P. Z., FORREST, A., UHLENBRAUCK, G., YOUNG, S., MCKINNEY R. JR., „Barriers to Change in the Informed Consent Process“, A Systematic Literature Review, May-June 2016, vol. 38, iss. 3. Dostupno na: http://www.thehastingscenter.org/.

HARTMAN, K. M., LIANG, A. B., „Exception to Informed Consent in Emergency Medicine“, Hospital Physician, 1999., 35, str. 53-59. Dostupno na: http://www.turner-white. com/pdf/hp_mar99_emergmed.pdf.

HOFMANN J., Ausgewählte Probleme der Eigenmächtigen Heilbehandlung im Rettungsdienst, 2017., dostupno na: https://www.oegern.at/wp/wp-content/uploads/

HORVATIĆ, Ž., DERENČINOVIĆ, D., CVITANOVIĆ L., Kazneno pravo, opći dio 2, Kazneno djelo i kaznenopravne sankcije, Zagreb, 2017., str. 306.

HUGHES, G., „Two Views On Consent In The Criminal Law“, Mod. L. Rev., 26, 1963., str. 233-248.

IVANČIĆ-KAČER, B., „Informed consent ili informirani pristanaka pacijenta na liječenje u hrvatskom pravu (s naglaskom na zaštiti prava liječnika)“, Pravo i porezi, 6, 2009., str. 10-22.

JEFFORD, M., MOORE, R., ,Improvement of informed consent and the quality of consent documents“, Lancet Oncol, 2008., 9, 5, str. 485-493.

JEREMIĆ, V., „Informirani pristanak: komunikacija između liječnika i bolesnika“, $J A H R$, vol. 4, no. 7, 2013., str. 525-533. 
Kazenski zakonik Slovenije, uradno prečiščeno besedilo (KZ-1-UPB2), Uradni list RS, št. 50/2012 z dne 29. 6. 2012, dostupno na https://www.uradni-list.si/1/content?id=109161\#!/ Kazenski-zakonik.

Kazneni zakonik Švedske (Ds 1999:36), dostupno na: http://www.government.se/conte ntassets/5315d27076c942019828d6c36521696e/swed.

KENNEDY, I., GRUBB, A., Medical Law, London, 2000.

KOH, L. K., „Doctrine Of Consent In Criminal Law“, Malaya L. Rev. 9, 1967., str. 181-201.

KOROŠEC, D., Medicinsko kazensko pravo, 2. izdanje, Ljubljana, 2016., str. 606.

KOROŠEC, D., Medicinsko kazensko pravo, Ljubljana, 2004., str. 384.

KOROŠEC, D., „Pravice zdravnikov v Sloveniji in Evropi (osebnostnopravni vidik) Physicians' Rights In Slovenia and Europe (From The Standpoint Of The Law Of Personal Rights)“", Zdrav vestn, 2006., 75, 645-651.

KRALJIĆ, S., „Informirana privolitev in pravica pacienta do obveščenosti v enotah intezivne medicine (s pregledom evropske sodne prakse)“, Zbornik radova s međunarodnog kongresa 1. Hrvatski kongres medicinskog prava s međunarodnim sudjelovanjem, 3-5. studenoga 2017., str. 213-226.

KURTOVIĆ MIŠIĆ, A., KRSTULOVIĆ DRAGIČEVIĆ, A., Kazneno pravo (Temeljni pojmovi i instituti), Split, 2014., str. 256.

KURTOVIĆ MIŠIĆ, A., „Osnove kaznenopravne odgovornosti zdravstvenih radnika“, Zbornik radova s međunarodnog simpozija „Medicinsko pravo u sustavu zdravstvene djelatnosti", Plitvice, 2015., str. 193-212.

LAUFS, A., UHLENBRUCK, W., Handbuch des Arztrechts, 3. Auflage, München, 2002.

MARKENSTEIN, F. L., Country Report The Netherlands u Zivilrechtliche Regelungen zur Absicherung der Patientenautonomie am Ende des Lebens (Regulations of Civil Law to Safeguard the Autonomy of patients at the End of Their Life), Springer, 2000., str. 741-772.

MARTINOVIĆ, I., „Problem uzročnosti u kaznenom pravu“, Hrvatski ljetopis za kazneno pravo i praksu, vol. 19, 1/2012., str. 75-104.

MIHUT, A., „The Respect for Human Dignity Throughout Life as Reflected in the New Civil Code“", Societate şi Politică, 2011., 5(9), str. 67-88. Dostupno na: http://socpol.uvvg. ro/image.

MILAS KLARIĆ, I., „Izjava volje za slučaj nesposobnosti“, Hrvatska pravna revija, 5, 2010., str. 61-71.

MILER, E., „Kriminalno-pravna odgovornost liječnika“, Hrestomatija hrvatskog medicinskog prava, Pravni fakultet, Zagreb, 2016., str. 41-68.

MIŠIĆ RADANOVIĆ, N., „Postupak prisilne (civilne) hospitalizacije prema Zakonu o zaštiti osoba s duševnim smetnjama“, Zbornik radova „Aktualnosti građanskog procesnog prava - nacionalna i usporedna pravnoteorijska i praktična dostignuća“, 2015., str. 410413. 
MUJOVIĆ-ZORNIĆ, H., PETROVIĆ, Z., „Odgovornost zdravstvenih ustanova za štete kao posledice lečenja (Responsibility of medical institutions for damages resulting from treatment)“, Vojnosanit Pregl, 2012., 69(8), str. 692-699.

MUJOVIĆ-ZORNIĆ, H., „Physician’s error: medical or legal concept?“, 29 Med. \& L., 2010., str. 159-169., dostupno na: http://heinonline.org.

NIKŠIĆ, S., ,Građanskopravna odgovornostzaliječenje bezpristanka“, Građanskopravna odgovornost u medicini, HAZU, Zagreb, 2008.

NOVOSELEC, P., BOJANIĆ, I., Opći dio kaznenog prava, Zagreb, 2013., str. 550.

PEPPIN, F. J., „Physician Neutrality and Patient Autonomy in Advance Directive Decisions“, Law \& Medicine, Vol. 11, No. 1, 1995., str. 13-27.

PICHLER, D., „Obaviješteni pristanak u obrascima suglasnosti kojima se prihvaća preporučeni dijagnostički odnosno terapeutski postupak Kliničkog bolničkog centra Osijek i njihova usklađenost s propisima i međunarodnom praksom“, Pravni vjesnik, god. 30, br. 1, 2014., str. 89-114.

QUAS M., ZUCK R., Medizinrecht, München, Verlag CH Beck, 2008.

RADIŠIĆ J., ,Dužnost lekara da pacijenta obavesti o rizicima predložene medicinske mere i njegova odgovornost - poseban osvrt na praksu nemačkih i austrijskih sudova“, Evropska revija za pravo osiguranja, 2, 2012., str. 32-43.

RADIŠIĆ, J., Odgovornost zbog štete izazvane lekarskom greškom u lečenju $i$ obaveštavanju pacijenta, Beograd, 2007.

RADIŠIĆ, J., „Pravna priroda odgovornosti medicinskih poslenika i njihovog odnosa s pacijentima“, Pravni život, br. 9/10., 1992., str. 1759-1771.

RADIŠIĆ, J., „Pristanak pacijenta na lečenje i odgovornost zbog lečenja bez punovažnog pristanka“, Evropska revija za pravo osiguranja, 1, 2012., str. 39-48.

RIJAVEC, V., GORIŠEK, J., FLIS, V., „Discussing medicine and law in Maribor“, ACTA MEDICO-BIOTECHNICA, 2011., 4, 1, str. 7-18.

ROKSANDIĆ VIDLIČKA, S., „Aktualna pitanja pojedinih kaznenih djela protiv zdravlja ljudi u svjetlu donošenja nacrta izmjena hrvatskog Kaznenog zakona“, Godišnjak APZH 2010.; 1: 93-146, Hrestomatija hrvatskog medicinskog prava, Pravni fakultet, Zagreb, 2016., str. 811-859.

ROXIN, C., SCHROTH, U., Medizinstrafrecht, Im Spannungsfeld von Medizin, Ethik und Strafrecht, 2. Aufl., Stuttgard, 2001.

ROXIN, C., Strafrecht, Allgemeiner Teil, Band I, 4. Auflage, München, 2006.

SELINGER, P. C., „The right to consent: Is it absolute?“, British Journal of Medical Practitioners, 2009., vol. 2, no. 2, str. 50-54. Dostupno na: http://www.bjmp.org/files/ june2009.

SJENIČIĆ, Ž. M., „Pristanak pacijenta na meru lečenja“, Zbornik Matice srpske za društvene nauke, br. 129, Novi Sad, 2009., str. 45-60.

SMITH, P. G. II, „The Vagaries Of Informed Consent“, INDIANA HEALTH LAW REVIEW, vol. 1, 2004., str. 109-129. 
SORTA BILAJAC, I., „Informirani pristanak - konceptualni, empirijski i normativni problemi Informed consent - conceptual, empirical and normative issues“, Medicina fluminensis 2011, Vol. 47, No. 1, p. 37-47.

SORTA BILAJAC, I., „Informirani pristanak u UNESCO-vim bioetičkim dokumentima“, JAHR, 2010; 1(1): 77-85.

Strafgesetzbuch BGBI.I.S 3322 (1998), 3671(2013), 3799 (2013), 1722(2015); dostupno na: http://www.gesetze-im-internet.de/englisch_stgb/englisch_stgb.html\#p i na: http://www. gesetze-im-internet.de/bundesrecht/stgb/gesamt.pdf.

ŠEPAROVIĆ, Z., „Presađivanje dijelova ljudskog tijela“, Hrestomatija hrvatskoga medicinskog prava, Zagreb, 2016., str. 621-627.

TOMIĆ, Z., Krivično pravo I - krivično djelo, Pravni fakultet, Sarajevo, 2007., str. 228.

TURKOVIĆ, K., „Informirani pristanak i pravo na odbijanje tretmana u Republici Hrvatskoj“, Hrestomatija hrvatskoga medicinskog prava, Zagreb, 2016., str. 551-566.

TURKOVIĆ, K., „Pravo na odbijanje medicinskog tretmana u Republici Hrvatskoj (Right to refuse medical treatment in Croatia)“, Medicina, 2008., vol. 44, 2, 158-170.

VERGAlo, M. G., FRATi, P., BUSARdó, F. P., MATTEO, G., ZAANi, S., CIANCOLINI, G., CORRENTI, F. R., DI LUCA, N. M., , The legislative reform of medical liability in Italy and the decriminalization of slight negligence: controversial issues", Prevention \& Research, 2, 2, 2013., str. 66-70.

VUČEMILO, L., BABIĆ-BOSANAC, S., ALTARAC, S., BOROVEČKI, A., „,Pristanak obaviještenog pacijenta s posebnim osvrtom na Hrvatsku“, Liječnički vjesnik, 2014., 136, str. 104-109.

VUKOVIĆ, I., „Pretpostavljeni pristanak u krivičnom pravu2, CRIMEN (V) 1, 2014., str. 50-61.

Zakon o liječništvu (NN br. 121/03. i 117/08.).

Zakon o obveznim odnosima, NN 35/05, 41/08, 125/11, 78/15, 29/18).

Zakon o zaštiti prava pacijenata (NN 169/04, 37/08).

ZEČEVIĆ, D., ŠKAVIĆ, J., Kaznenopravna i građanskopravna odgovornost liječnika - teorija i praksa, Medicinska naklada, Zagreb, 2012., str. 247.

ŽUNIĆ, LJ., Prava i dužnosti pacijenta u ostvarivanju zdravstvene zaštite, Split, 2016., str. 153.

WEYANDT, J. C., , Valid consent to medical treatment: need the patient know?“, Duq. U. L. Rev., 4, 1965.-1966., str. 450-462.

WIENKE, A., Errors and pitfalls: Briefing and accusation of medical malpractice - the second victim, German Medical Science Current Topics in Otorhinolaryngology - Head and Neck Surgery 2013, vol. 12, str. 24. Dostupno na: http://www.egms.de/static/pdf/journals/ cto/.

WNICK, J. B., „Advance Directive Instruments for Those with Mental Illness“, University of Miami Law Review, 51, 1996.-1997., str. 57-95. , 


\section{PACIENT CONSENT TO MEDICAL PROCEDURES AS A REASON TO EXCLUDE ILLEGALITY}

Even though the injured party's consent is a concept materially identical in civil and criminal law, its effect is different. While in Croatian law on damages, legal patient consent as an injured party excludes the illegality of medical intervention, this is not the case in criminal law. Due to the complexity of this problem area, the concepts of various types of patint consent are analyzed from assumed consent, replacement or surrogate consent to anticipated orders/proxy in cases of incapacity and in particular analyzes all the conditions necessary for its validity. Given that various viewpoints on the effect of consent by the injured party exist in criminal law, here in particular two opposing stances represented in comparative law are shown related to the effect of patient consent on medical procedures. A normative model is shown of the exculpation effect of consent where causing grievous bodily harm in treatment or activities with the aim of treatment is not illegal if the patient has given consent in the form or under the conditions prescribed by law. Also, a model by which the consent of the injured party is important only for the essence of the act is also shown.

Key words: informed patient consent, excluding illegality, negligent treatment 